\title{
Dissolved inorganic carbon and alkalinity fluxes from coastal marine sediments: model estimates for different shelf environments and sensitivity to global change
}

\author{
V. Krumins ${ }^{1, *}$, M. Gehlen ${ }^{2}$, S. Arndt ${ }^{3}$, P. Van Cappellen ${ }^{4}$, and P. Regnier ${ }^{1,5}$ \\ ${ }^{1}$ Department of Earth Sciences - Geochemistry, Faculty of Geosciences, Utrecht University, 3584CD Utrecht, \\ The Netherlands \\ ${ }^{2}$ LSCE/IPSL, Laboratoire des Sciences du Climat et de l'Environnement, 91191 Gif-sur-Yvette Cedex, France \\ ${ }^{3}$ School of Geographical Sciences, University of Bristol, BS8 1SS Bristol, UK \\ ${ }^{4}$ Department of Earth and Environmental Sciences, University of Waterloo, Waterloo, ON N2L 3G1, Canada \\ ${ }^{5}$ Department of Earth and Environmental Sciences, CP 160/02, Université Libre de Bruxelles, 1050 Brussels, Belgium \\ * current address: Department of Environmental Sciences, Rutgers University, New Brunswick, NJ, USA
}

Correspondence to: V. Krumins (krumins@envsci.rutgers.edu)

Received: 30 May 2012 - Published in Biogeosciences Discuss.: 17 July 2012

Revised: 14 December 2012 - Accepted: 17 December 2012 - Published: 24 January 2013

\begin{abstract}
We present a one-dimensional reactive transport model to estimate benthic fluxes of dissolved inorganic carbon (DIC) and alkalinity $\left(A_{\mathrm{T}}\right)$ from coastal marine sediments. The model incorporates the transport processes of sediment accumulation, molecular diffusion, bioturbation and bioirrigation, while the reactions included are the redox pathways of organic carbon oxidation, re-oxidation of reduced nitrogen, iron and sulfur compounds, pore water acid-base equilibria, and dissolution of particulate inorganic carbon (calcite, aragonite, and Mg-calcite). The coastal zone is divided into four environmental units with different particulate inorganic carbon (PIC) and particulate organic carbon (POC) fluxes: reefs, banks and bays, carbonate shelves and non-carbonate shelves. Model results are analyzed separately for each environment and then scaled up to the whole coastal ocean. The model-derived estimate for the present-day global coastal benthic DIC efflux is $126 \mathrm{Tmol} \mathrm{yr}^{-1}$, based on a global coastal reactive POC depositional flux of $117 \mathrm{Tmol} \mathrm{yr}^{-1}$. The POC decomposition leads to a carbonate dissolution from shallow marine sediments of $7 \mathrm{Tmol} \mathrm{yr}^{-1}$ (on the order of $0.1 \mathrm{Pg} \mathrm{C} \mathrm{yr}^{-1}$ ). Assuming complete re-oxidation of aqueous sulfide released from sediments, the effective net flux of alkalinity to the water column is 29 Teq. $\mathrm{yr}^{-1}$, primarily from PIC dissolution $(46 \%)$ and ammonification $(33 \%)$. Because our POC depo-
\end{abstract}

sitional flux falls in the high range of global values given in the literature, the reported DIC and alkalinity fluxes should be viewed as upper-bound estimates. Increasing coastal seawater DIC to what might be expected in year 2100 due to the uptake of anthropogenic $\mathrm{CO}_{2}$ increases PIC dissolution by $2.3 \mathrm{Tmol} \mathrm{yr}^{-1}$ and alkalinity efflux by $4.8 \mathrm{Teq} . \mathrm{yr}^{-1}$. Our reactive transport modeling approach not only yields global estimates of benthic DIC, alkalinity and nutrient fluxes under variable scenarios of ocean productivity and chemistry, but also provides insights into the underlying processes.

\section{Introduction}

Based on globally averaged carbon box models driven by atmospheric $\mathrm{CO}_{2}$, globally averaged land-use changes and climate, Andersson et al. (2005) recently estimated that the coastal ocean currently receives $\sim 80 \mathrm{Tmol}$ (inorganic and organic) $\mathrm{C} \mathrm{yr}^{-1}$ from terrestrial sources, pumps $\sim 20 \mathrm{Tmol} \mathrm{Cyr}^{-1}$ from the atmosphere and sequesters on the order of $40 \mathrm{Tmol} \mathrm{C} \mathrm{yr}^{-1}$ in shallow marine sediments. Because the deposition flux of carbon could exceed its burial flux by a factor of two or so (e.g., Andersson et al., 2005), the dissolved inorganic carbon (DIC) recycling flux from both benthic organic matter degradation and carbonate 
Table 1. Global C flux estimates in coastal sediments.

\begin{tabular}{|c|c|c|}
\hline & Global estimate ( $\mathrm{Tmol} \mathrm{C} \mathrm{yr}^{-1}$ ) & Reference \\
\hline \multirow[t]{8}{*}{ POC deposition flux } & 15.6 & Jahnke (2010) \\
\hline & 40 (pre-industrial) & Andersson et al. (2005) \\
\hline & 52 & Muller-Karger et al. (2005) \\
\hline & 97 (0-150 m, reactive only) & Thullner et al. (2009) \\
\hline & 117 (reactive only) & This work \\
\hline & 135 & Dunne et al. (2007) \\
\hline & 167 & Wollast (1991) \\
\hline & 183 & Sarmiento and Gruber (2006) \\
\hline \multirow[t]{9}{*}{ POC burial } & 5 & Muller-Karger et al. ( 2005) \\
\hline & 9 & Andersson et al. (2005) \\
\hline & 10 & Berner (1982) \\
\hline & 14.2 & Sarmiento and Gruber (2006) \\
\hline & 15 & Chen (2003) \\
\hline & 17 & Wollast (1991) \\
\hline & $18-20$ & Wollast and Mackenzie (1989) \\
\hline & 20 & Mackenzie et al. (1998) \\
\hline & 56 & Dunne et al. (2007) \\
\hline \multirow[t]{3}{*}{ PIC deposition } & 23 & Milliman and Droxler (1996) \\
\hline & 23 & This work \\
\hline & 24.5 (not including inert riverine PIC) & Andersson et al. (2005) \\
\hline \multirow[t]{6}{*}{ PIC burial } & 13 & Milliman and Droxler (1996) \\
\hline & 14.5 (not including inert riverine PIC) & Andersson et al. (2005) \\
\hline & 15 & Chen (2003) \\
\hline & 16 & This work \\
\hline & 17 & Feely et al. (2004) \\
\hline & 21 & Mackenzie et al. (1998) \\
\hline
\end{tabular}

dissolution may be on the order of $40 \mathrm{Tmol} \mathrm{C} \mathrm{yr}^{-1}$. These estimates are supported to some extent by observational evidence (e.g., Mackenzie et al., 2005) and clearly highlight the prominent role of shallow sediments in the global coastal ocean carbon budget. A number of recent studies have also discussed the potential importance of alkalinity generation in shallow sediments to the global ocean alkalinity budget, suggesting that the benthic alkalinity source could act as negative feedback to rising atmospheric $\mathrm{CO}_{2}$ conditions and ocean acidification (Chen, 2002; Chen et al., 2003; Thomas et al., 2009; Hu and Cai, 2011). This benthic source of alkalinity to the overlying water column has mainly been attributed to anaerobic degradation pathways of deposited organic matter. For instance, Thomas et al. (2009) propose that the 0.073 Teq. $\mathrm{yr}^{-1}$ of alkalinity generated in the Wadden Sea are produced by denitrification and sulfate reduction. This release could balance $20-25 \%$ of the $\mathrm{CO}_{2}$ uptake of the entire North Sea. By extrapolating budgets for the East China Sea, Chen (2002) estimates that continental margin sediments contribute $16-31$ Teq. $\mathrm{yr}^{-1}$ of alkalinity globally, a value that is comparable to the global bicarbonate alkalinity delivered by rivers (Suchet et al., 2003). Hu and Cai (2011), however, obtained a much smaller benthic alkalinity flux of 4-5 Teq. $\mathrm{yr}^{-1}$ based on whole-ocean estimates of denitrification and sulfate reduction in sediments deposited on the continental shelves.

Because of the limited availability of comprehensive observational datasets that can resolve the heterogeneity of the global coastal ocean, it is nonetheless important to recognize that the quantitative global significance of coastal sediments to the carbon cycle, DIC and alkalinity generation fluxes remains poorly known. For instance, only a few estimates of PIC (particulate inorganic carbon) deposition fluxes in the coastal zone are available $\left(23-24.5 \mathrm{Tmol} \mathrm{yr}^{-1}\right.$, Table 1), while global estimates of particulate organic carbon (POC) deposition fluxes for seafloor depths between 0 and $200 \mathrm{~m}$ vary by an order of magnitude (16-183 $\mathrm{Tmol} \mathrm{C} \mathrm{yr}^{-1}$, Table 1). The large uncertainties associated with the deposition fluxes and post-depositional fate of POC and PIC lead to poorly constrained inorganic carbon budgets and benthic fluxes for shallow marine sediments (see, for example, Schneider et al., 2006).

Most commonly, benthic alkalinity fluxes are derived indirectly by balancing water column budgets; that is, they are not based on an explicit representation of the benthic compartment and the alkalinity-generating early diagenetic processes. However, over the past three decades, early diagenetic modeling has greatly improved our mechanistic 
and quantitative understanding of biogeochemical cycling in marine sediments and should thus be considered a method of choice to quantify benthic alkalinity and DIC fluxes. A few studies have fully addressed the dynamic interplay between redox processes, driven by organic matter decomposition, and inorganic carbonate dissolution and precipitation (Boudreau and Canfield, 1993; Jourabchi et al., 2005; Burdige et al., 2010). Most early diagenetic modeling studies that explore biogeochemical dynamics in shallow water environments tend nevertheless to be site-specific, with little attempt to extrapolate the results to larger scales. (e.g., Blair and Aller, 1995; Martens et al., 1998; Epping et al., 2002; Berg et al., 2003; Luff and Moll, 2004; Rojas and Silva, 2005; Thullner et al., 2005; Morse and Eldridge, 2007; Dale et al., 2008, 2009; Anggara Kasih et al., 2008; Mogollon et al., 2009). Soetaert et al. (1996) developed an early diagenetic model of sediments from the shelf $(200 \mathrm{~m})$ to the abyss $(3000 \mathrm{~m})$, which quantified carbon oxidation via oxic and anoxic pathways. The recent study by Thullner et al. (2009) also quantifies organic carbon oxidation pathways along an ocean hypsometry from 100 to $5000 \mathrm{~m}$, and determines the associated dissolved inorganic carbon (DIC) fluxes. A number of coupled global biogeochemical models such as GENIE (Ridgwell, 2007; Ridgwell and Hargreaves, 2007), CLIMBER and UVic (Archer et al., 2009), and HAMMOC (Palastanga et al., 2011) also apply simplified models of early diagenesis (e.g., Muds (Archer et al., 2002) or the DCESS sediment module of Shaffer et al., 2008). However, these global models cannot resolve the shallow ocean dynamics and their diagenetic components are typically based on simplifying assumptions such as considering a single PIC phase (calcite) or neglecting Fe cycling/burial.

The limited quantitative understanding of benthic alkalinity and DIC fluxes from shallow marine environments contrasts with the potential significance of coastal sediments for the global carbon cycle and climate. In particular, our ability to better constrain global coastal ocean $\mathrm{C}$ budgets will strongly depend on a better quantification of biogeochemical transformations and fluxes in these shallow sediments. In addition, such quantification will also improve our ability to predict the response of the seafloor to perturbations of the carbon cycle, including productivity changes and acidification of coastal waters. For instance, Andersson et al. (2005) predict that increasing coastal productivity over the next century will significantly alter the $\mathrm{CO}_{2}$ pumping efficiency of the global coastal ocean. This eutrophication will increase POC deposition fluxes, and, because organic carbon metabolism is the major driving force for PIC dissolution in shallow environments (Morse and Mackenzie, 1990), benthic carbonate dissolution will increase. In contrast, model simulations by Andersson et al. (2005) indicate that ocean acidification, and the resulting $\mathrm{pH}$ drop of circa 0.3 units predicted by the end of the century (e.g., Caldeira and Wickett, 2003), should have a limited impact on benthic $\mathrm{CaCO}_{3}$ dissolution. Nevertheless, this conclusion requires further investigation, because it is drawn from simple mass balance calculations, which do not resolve the complex interplay between the large number of benthic processes.

The purpose of this contribution is to determine the quantitative significance of major early diagenetic processes for the production and consumption of DIC and alkalinity, as well as their benthic fluxes in coastal ocean sediments, for both present-day conditions and in response to coastal ocean eutrophication and acidification scenarios. To this end, a onedimensional (1-D) reactive transport model (RTM) of benthic organic carbon and inorganic carbon dynamics is presented. We simulate organic carbon oxidation pathways, reoxidation of reduced nitrogen, iron and sulfur compounds, pore water acid-base equilibria, and dissolution of particulate inorganic carbon (calcite, aragonite, and $\mathrm{Mg}$-calcite). In addition, we distinguish between four different carbonate environments and a number of distinct environmental sub-units that are characterized by different biogeochemical drivers. The RTM is then applied to quantify the impact of early diagenetic reactions on the dissolution of three carbonate phases (calcite, aragonite, and a 15\% Mg-calcite) and the benthic DIC and alkalinity fluxes for each of the identified carbonate environments. We also provide a first-order estimate of the global alkalinity and DIC fluxes from marine sediments to the shallow coastal zone by extrapolating our regional results to the scale of the global coastal ocean. Furthermore, we assess the sensitivity of benthic DIC and alkalinity fluxes in each environment to uncertainties associated with the benthic iron and sulfur cycles. Finally, we explore the response of DIC and alkalinity fluxes to changes in organic and inorganic carbon deposition fluxes due to eutrophication and ocean acidification, respectively.

\section{Methods}

\subsection{Model environments}

The coastal ocean is one of the most complex and heterogeneous aquatic environments in the Earth system. One way to deal with this heterogeneity is to propose a classification of the coastal ocean into different environments with broadly similar characteristics, organized according to series of hierarchically related system levels (Table 2). Each hierarchical level describes a level of organization that controls DIC and alkalinity fluxes at a specific spatial scale. Processes at higher levels have a direct influence on lower level characteristics, and smaller scales are nested within larger scales.

At the highest hierarchical level (Level I), the coastal ocean can be divided into distinct environments, each characterized by a distinct mode of carbonate production and accumulation (input control). Here, we follow the wellestablished classification proposed by Milliman and Droxler (1996) into four different types of shallow-water carbonate environments: reefs, banks and bays, carbonate shelves, 
Table 2. Hierarchical classification scheme (see text for details).

\begin{tabular}{|c|c|c|c|c|}
\hline & Controlling Factor & Characteristics & & Scenarios \\
\hline \multirow[t]{4}{*}{ Level I } & Mode of carbonate & $J_{\mathrm{PIC}}$ & 1 & Reefs \\
\hline & Production/accumulation & & 2 & Banks \& embayments \\
\hline & & & 3 & Carbonate shelve \\
\hline & & & 4 & Non-carbonate shelves \\
\hline \multirow[t]{4}{*}{ Level II } & Carbonate dissolution & $J_{\mathrm{POC}}, \mathrm{O}_{2}, \mathrm{NO}_{3}, \mathrm{SO}_{4}$ & 1 & Globally averaged conditions for reefs \\
\hline & & & 2 & $\begin{array}{l}\text { Globally averaged conditions for } \\
\text { banks \& embayments }\end{array}$ \\
\hline & & & 3 & $\begin{array}{l}\text { Globally averaged conditions for } \\
\text { carbonate shelves }\end{array}$ \\
\hline & & & 4 & $\begin{array}{l}\text { Globally averaged conditions for non- } \\
\text { carbonate shelves }\end{array}$ \\
\hline \multirow[t]{4}{*}{ Level III } & Local variability & water depth master variable & 1 & Average water depth $25 \mathrm{~m}$ \\
\hline & & for variability in & 2 & Average water depth $25 \mathrm{~m}$ \\
\hline & & $J_{\mathrm{POC}}, J_{\mathrm{PIC}}, \mathrm{O}_{2}, \mathrm{NO}_{3}$ & 3 & $25,75,150 \mathrm{~m}$ \\
\hline & & $\mathrm{SO}_{4}, w, \alpha, D_{\mathrm{b}}$ & 4 & $25,75,150 \mathrm{~m}$ \\
\hline
\end{tabular}

and non-carbonate shelves. Reefs comprise coral reefs and lagoons and show the highest carbonate production on an area basis in the present-day ocean. Accumulated carbonates mainly originate from corals and algae and, locally, also from foraminifera (e.g., Milliman, 1993). Banks and embayments encompass tropical and sub-tropical, littoral and sub-littoral environments that are characterized by high rates of carbonate production and accumulation, sustained by benthic algae, mollusks, benthic foraminifera and locally also bryozoans and serpulids (e.g., Stockman et al., 1967; Boscence et al., 1985). In contrast to the reef and bank environments, the production and accumulation of carbonates on continental shelves have certainly not been surveyed to the same extent. We use the same divisions as Milliman and Droxler (1996) in dividing the continental shelf according to its carbonate content into carbonate and non-carbonate shelves . In these environments, carbonate production is generally supported by benthic and pelagic production, as well as relict components, such as oysters, ooids and dead coral reefs (e.g., Milliman, 1993 and references therein).

At the next hierarchical level (Level II), the environmental units identified above should be further subdivided into regions that are characterized by similar controls on carbonate dissolution. Previous research has shown that organic matter degradation exerts a dominant control on benthic carbonate dissolution through the production of metabolic carbon dioxide, the associated lowering of the pore water $\mathrm{pH}$ and, thus, the saturation state (e.g., Jahnke et al., 1994). In this context, the magnitude and quality of the organic matter deposition flux is a fundamental control factor of the carbonate dissolution fluxes. In addition, anoxic degradation pathways generally produce alkalinity and, therefore, favor carbonate preservation or even precipitation. Thus, the bottom water concentrations of the dominant terminal electron ac- ceptors $\mathrm{O}_{2}, \mathrm{NO}_{3}$ and $\mathrm{SO}_{4}$ are additional control factors on carbonate dissolution, since they determine the relative contribution of aerobic and anaerobic decomposition pathways. However, the spatial variability in the magnitude and quality of the organic matter deposition flux remains extremely difficult to assess, since coastal fluxes generally represent a dynamic mixture of organic matter from terrestrial, lateral and in situ sources (e.g., Mollenhauer and Eglinton, 2007; Mollenhauer et al., 2005). This lack of quantitative understanding about the fate of coastal organic matter is also reflected in the large variability in the global estimates of organic matter deposition fluxes for seafloor depths between 0 and $200 \mathrm{~m}$

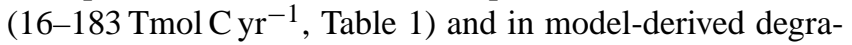
dation rate constants (Arndt et al., 2011).

Therefore, further regionalization based on organic matter and redox criteria is not achievable at this stage and we choose to extract average environmental conditions for each of the four environmental units selected at Level I only. Values are either extracted from the literature or derived from the $1^{\circ}$ dataset of the Levitus94 database (NOAA World Ocean Atlas 1994, available online at http://iridl.ldeo.columbia.edu/). This simplified approach can be seen as a first step towards a better regional classification of the coastal ocean in terms of the dominant controls on carbonate chemistry. It also implies that our results only provide a first-order global estimate of DIC and alkalinity fluxes for the coastal ocean.

On a local scale, depositional fluxes, bottom water concentrations and transport parameters often show a strong correlation with water depth (e.g., Soetaert et al., 2002; Epping et al., 2002). Pressure, and thus water depth, also directly affects the solubility products of the various carbonate phases. Water depth is thus used at Level III of our classification, and we assume an average value of $25 \mathrm{~m}$ for the 
reefs, and the banks and bays. The shelves are further subdivided into three depth ranges: $0-50 \mathrm{~m}, 50-100 \mathrm{~m}$, and 100 $200 \mathrm{~m}$. These depth intervals contribute 41,31 , and $28 \%$ of the global coastal seafloor area shallower than $200 \mathrm{~m}$, respectively, based on the data of Smith and Sandwell (1997) extracted from a $\sim \frac{1}{2}$ min regridding from $72^{\circ} \mathrm{N}$ to $72^{\circ} \mathrm{S}$, accessed online at http://www.grdl.noaa.gov/cgi-bin/bathy/ bathD.pl.

\subsection{Model approach}

A 1-D reactive transport model for coastal sediments is developed using the Biogeochemical Reaction Network Simulator (Regnier et al., 2002; Aguilera et al., 2005), which has previously been used to simulate mixed kineticequilibrium reaction networks describing early diagenesis (e.g., Jourabchi et al., 2005; Thullner et al., 2005). The vertical concentration fields in the sediment are modeled using the 1-D advection-diffusion-reaction equations:

$\varphi \frac{\partial C_{i}}{\partial t}=\frac{-\partial\left(\omega \varphi C_{i}\right)}{\partial x}+\frac{\partial}{\partial x}\left\{\left(D_{\mathrm{b}}+D_{i}\right) \frac{\partial\left(\varphi C_{i}\right)}{\partial x}\right\}+\alpha_{i}\left(C_{i 0}-C_{i}\right)+\sum R_{i}(1)$

and

$(1-\varphi) \frac{\partial C_{i}}{\partial t}=\frac{-\partial\left(\omega(1-\varphi) C_{i}\right)}{\partial x}+\frac{\partial}{\partial x}\left\{D_{\mathrm{b}} \frac{\partial\left((1-\varphi) C_{i}\right)}{\partial x}\right\}+\sum R_{i}$

for solutes and solid-bound species, respectively. In the above equations, $x$ is depth below the sediment-water interface $(\mathrm{cm})$, and

$$
\begin{aligned}
& \varphi=\text { porosity [ ] (assumed to be constant in time), } \\
& \omega=\text { sediment burial velocity }\left[\mathrm{cm} \mathrm{yr}^{-1}\right], \\
& C_{i}=\text { concentration of species } i \text { at depth } x \text { and time } t \\
& {\left[\mu \mathrm{mol} \mathrm{cm}{ }^{-3}\right] \text {, }} \\
& C_{i 0}=\text { concentration of } i \text { at sediment-water interface } \\
& {\left[\mu \mathrm{mol} \mathrm{cm}^{-3}\right. \text { ], }} \\
& D_{\mathrm{b}}=\text { bioturbation coefficient }\left[\mathrm{cm}^{2} \mathrm{yr}^{-1}\right] \text {, } \\
& D_{i}=\text { molecular diffusion coefficient of solute species } i \\
& {\left[\mathrm{~cm}^{2} \mathrm{yr}^{-1}\right] \text {, }} \\
& \alpha_{i}=\text { non-local bioirrigation coefficient }\left[\mathrm{yr}^{-1}\right] \text {, and } \\
& \Sigma R_{i}=\text { net rate of all reactions involving species } i \\
& {\left[\mu \mathrm{mol} \mathrm{cm}{ }^{-3} \mathrm{yr}^{-1}\right] \text {. }}
\end{aligned}
$$

A discretized version of Eq. (1) is solved with an operator splitting approach for the transport and reaction terms. Solute transport is discretized using the Crank-Nicholson algorithm, while for solids and sorbed species (Eq. 2) a flux limiting total variation diminishing scheme is used (e.g., Regnier et al., 1998). The reaction term is cast as a set of differential algebraic equations (DAEs) and solved using a Newton algorithm (for further details, see Aguilera et al., 2005; Centler et al., 2010). A $5 \times 10^{-6}$ yr time step is imposed for transient simulations that are run until steady state (generally 200-400 simulation years are required for the concentration profiles to adjust to their final configurations from arbitrary initial profiles. This is approximately the time required to advect the solid phase through the modeling domain.). The modeled sediment thickness is $50 \mathrm{~cm}$, discretized in 116 irregularly spaced nodes. Node spacing varies from $0.1 \mathrm{~cm}$ at the sediment-water interface to $2 \mathrm{~cm}$ at the base of the modeled sediment column.

\subsection{Transport}

The choice of transport parameters is guided by empirically determined global values or global relationships proposed in the literature. The sediment advection (burial) rate $(\omega$, $\mathrm{cm} \mathrm{yr}^{-1}$ at the sediment-water interface (SWI)) and bioturbation coefficient $\left(D_{\mathrm{b} 0}\right)$ are obtained from the global depth relationships proposed by Middelburg et al. (1997):

$\omega=3.3 \times 10^{(-0.87478367-0.00043512 \cdot \mathrm{SFD})}$

$D_{\mathrm{b} 0}=5.2 \times 10^{(0.76241122-0.00039724 \cdot \mathrm{SFD})}$,

where SFD is the seafloor depth in meters.

A global average bioturbation depth of $10 \mathrm{~cm}$ in marine sediments (Boudreau, 1994) is assumed for all environments and water depths. A complementary error function is used to attenuate the bioturbation coefficient with depth. Thus at $10 \mathrm{~cm}, D_{\mathrm{b}}$ is $50 \%$ of the value at the SWI. At $15 \mathrm{~cm}$, it is $4 \%$ of the value at the surface. An exponential decay function is imposed for the porosity $(\varphi)$ depth profile (Wang and Van Cappellen, 1996):

$\varphi(x)=0.75+0.1 e^{-0.15 x}$.

Diffusion coefficients for the dissolved species are corrected for temperature and sediment porosity according to Boudreau (1996). Bioirrigation intensity is assumed to decrease exponentially with depth in the sediment:

$\alpha(x)=\alpha_{0} \cdot e^{\left(-x / x_{\text {irr }}\right)}$

where $\alpha_{0}$ is the bioirrigation coefficient at the sedimentwater interface $\left(\mathrm{yr}^{-1}\right)$, and $x_{\text {irr }}$ is a depth attenuation coefficient $(\mathrm{cm})$. The value of $x_{\text {irr }}$ is set to $3.5 \mathrm{~cm}$, while $\alpha_{0}$ is estimated following Thullner et al. (2009).

Some of the dissolved oxygen that is transported into the sediment via bioirrigation will oxidize reduced iron in the vicinity of burrows. The iron (oxy)hydroxide precipitates sorb aqueous phosphate (e.g., Spiteri et al., 2008), hence reducing the apparent irrigational transport of phosphate. Berg et al. (2003) and Meile et al. (2005) showed that effective bioirrigation rates differ widely among chemical species depending on their behavior at burrow walls. For instance, according to Berg et al. (2003), $\alpha \approx 0$ for $\mathrm{Fe}^{2+}$. Rather than 
Table 3. Kinetic and equilibrium reactions, and generation of DIC and $A_{\mathrm{T}}$.

\begin{tabular}{|c|c|c|c|}
\hline Reaction & & DIC & $A_{\mathrm{T}}$ \\
\hline \multicolumn{4}{|c|}{ Hydrolysis } \\
\hline$(\mathrm{R} 1, \mathrm{R} 2)$ & $\frac{1}{106}\left(\mathrm{CH}_{2} \mathrm{O}\right)_{106}\left(\mathrm{NH}_{3}\right)_{16}\left(\mathrm{H}_{3} \mathrm{PO}_{4}\right)+\frac{15}{106} \mathrm{H}^{+} \rightarrow \mathrm{CH}_{2} \mathrm{O}+\frac{16}{106} \mathrm{NH}_{4}^{+}+\frac{1}{106} \mathrm{H}_{2} \mathrm{PO}_{4}^{-}$ & 0 & +0.14 \\
\hline \multicolumn{4}{|c|}{ Primary redox reactions } \\
\hline (R3) & $\mathrm{CH}_{2} \mathrm{O}+\mathrm{O}_{2} \rightarrow \mathrm{CO}_{2}+\mathrm{H}_{2} \mathrm{O}$ & +1 & 0 \\
\hline (R4) & $\mathrm{CH}_{2} \mathrm{O}+0.8 \mathrm{NO}_{3}^{-}+0.8 \mathrm{H}+\rightarrow \mathrm{CO}_{2}+0.4 \mathrm{~N}_{2}+1.4 \mathrm{H}_{2} \mathrm{O}$ & +1 & +0.8 \\
\hline (R5) & $\mathrm{CH}_{2} \mathrm{O}+4 \mathrm{Fe}(\mathrm{OH})_{3}+8 \mathrm{H}^{+} \rightarrow \mathrm{CO}_{2}+4 \mathrm{Fe}^{2+}+11 \mathrm{H}_{2} \mathrm{O}$ & +1 & +8 \\
\hline (R6) & $\mathrm{CH}_{2} \mathrm{O}+\frac{1}{2} \mathrm{SO}_{4}^{2-}+\frac{1}{2} \mathrm{H}^{+} \rightarrow \mathrm{CO}_{2}+\frac{1}{2} \mathrm{HS}^{-}+\mathrm{H}_{2} \mathrm{O}$ & +1 & +1 \\
\hline \multicolumn{4}{|c|}{ Secondary redox reactions } \\
\hline (R7) & $\frac{1}{2} \mathrm{NH}_{4}^{+}+\mathrm{O}_{2} \rightarrow \frac{1}{2} \mathrm{NO}_{3}^{-}+\frac{1}{2} \mathrm{H}_{2} \mathrm{O}+\mathrm{H}^{+}$ & 0 & -1 \\
\hline (R8) & $4 \mathrm{Fe}^{2+}+\mathrm{O}_{2} \rightarrow 4 \mathrm{Fe}(\mathrm{OH})_{3}+8 \mathrm{H}^{+}$ & 0 & -8 \\
\hline (R9) & $\frac{1}{2} \mathrm{HS}^{-}+\mathrm{O}_{2} \rightarrow \frac{1}{2} \mathrm{SO}_{4}^{-}+\frac{1}{2} \mathrm{H}^{+}$ & 0 & -1 \\
\hline (R10) & $\frac{1}{2} \mathrm{FeS}+\mathrm{O}_{2} \rightarrow \frac{1}{2} \mathrm{Fe}^{2+}+\frac{1}{2} \mathrm{SO}_{4}^{2-}$ & 0 & 0 \\
\hline \multicolumn{4}{|c|}{ PIC dissolution } \\
\hline (R11) & $\mathrm{CaCO}_{3}$ (calcite) $\rightarrow \mathrm{Ca}^{2+}+\mathrm{CO}_{3}^{2-}$ & +1 & +2 \\
\hline (R12) & $\mathrm{CaCO}_{3}$ (aragonite) $\rightarrow \mathrm{Ca}^{2+}+\mathrm{CO}_{3}^{2-}$ & +1 & +2 \\
\hline (R13) & $\mathrm{Ca}_{0.85} \mathrm{Mg}_{0.15} \mathrm{CO}_{3} \rightarrow 0.85 \mathrm{Ca}^{2+}+0.15 \mathrm{Mg}^{2+}+\mathrm{CO}_{3}^{2-}$ & +1 & +2 \\
\hline \multicolumn{4}{|c|}{ Other kinetic reactions } \\
\hline (R14) & $\mathrm{Fe}^{2+}+\mathrm{HS}^{-} \rightarrow \mathrm{FeS}+\mathrm{H}^{+}$ & 0 & -2 \\
\hline (R15) & $\mathrm{FeS}+\mathrm{H}_{2} \mathrm{~S} \rightarrow \mathrm{H}_{2}+\mathrm{FeS}_{2}$ & 0 & 0 \\
\hline (R16) & $\mathrm{Fe}^{2+}+\mathrm{CO}_{3}^{2-} \rightarrow \mathrm{FeCO}_{3}$ & -1 & -2 \\
\hline (R17) & $\mathrm{H}_{2} \mathrm{~S}+$ inert-POC $\rightarrow$ organic-S & 0 & 0 \\
\hline \multicolumn{4}{|l|}{ Equilibria } \\
\hline & $\mathrm{H}_{2} \mathrm{CO}_{3} * \leftrightarrow \mathrm{H}^{+}+\mathrm{HCO}_{3}^{-}$ & & \\
\hline & $\mathrm{HCO}_{3}^{-} \leftrightarrow \mathrm{H}^{+}+\mathrm{CO}_{3}^{2-}$ & & \\
\hline & $\mathrm{H}_{2} \mathrm{O} \leftrightarrow \mathrm{H}^{+}+\mathrm{OH}^{-3}$ & & \\
\hline & $\mathrm{H}_{2} \mathrm{~S} \leftrightarrow \mathrm{H}^{+}+\mathrm{HS}^{-}$ & & \\
\hline & $\mathrm{B}(\mathrm{OH})_{3}+\mathrm{H}_{2} \mathrm{O} \leftrightarrow \mathrm{H}^{+}+\mathrm{B}(\mathrm{OH})_{4}^{-}$ & & \\
\hline & $\mathrm{Fe}(\mathrm{OH})_{3}+\mathrm{H}_{2} \mathrm{PO}_{4}^{-} \leftrightarrow$ iron-sorbed-P & & \\
\hline & $\mathrm{H}_{2} \mathrm{PO}_{4}^{-} \leftrightarrow$ sorbed-P & & \\
\hline & $\mathrm{Fe}^{2+} \leftrightarrow$ ↔ sorbed-Fe & & \\
\hline & $\mathrm{NH}_{4}^{+} \leftrightarrow$ sorbed- $\mathrm{NH}_{4}$ & & \\
\hline
\end{tabular}

Reaction numbers for reference to Tables 2 and 3.

DIC - mol of DIC generated or consumed for the reaction as written.

$A_{\mathrm{T}}-$ eq. of alkalinity generated or consumed for the reaction as written.

Equilibrium reactions do not lead to any net generation of DIC or alkalinity.

modifying $\alpha$ (in Eq. 1), Katsev et al. (2007) reduced the local concentrations of $\mathrm{Fe}^{2+}$ and phosphate by a factor of 0.1 to account for reduced bio-irrigation. Here, we chose to multiply $\alpha$ calculated according to Eq. (6) by 0.01 for $\mathrm{Fe}^{2+}$ and $\mathrm{H}_{2} \mathrm{PO}_{4}^{-}$. This corresponds roughly to the ratio of the depthintegrated $\alpha$ value for $\mathrm{Fe}^{2+}$ to that of solutes such as $\mathrm{O}_{2}$ or $\mathrm{NH}_{4}^{+}$in Meile et al. (2005).

\subsection{Reactions}

\subsubsection{POC hydrolysis (R1-2)}

Organic matter in the sediments is assumed to have Redfield stoichiometry: $\left(\mathrm{CH}_{2} \mathrm{O}\right)_{106}\left(\mathrm{NH}_{3}\right)_{16}\left(\mathrm{H}_{3} \mathrm{PO}_{4}\right)$ (Table 3, $\mathrm{R} 1$ and R2). Organic matter degradation is modeled as a two-step process. It is first hydrolyzed to yield dissolved organic carbon (DOC), ammonia and phosphate. Hydrolysis rates are assumed to exhibit a first-order dependence on 
the concentrations of the reactive POC pools. Ammonia released during POC hydrolysis is protonated to ammonium $\left(\mathrm{NH}_{4}^{+}\right)$, while phosphate is released as dihydrogen phosphate $\left(\mathrm{H}_{2} \mathrm{PO}_{4}^{-}\right)$, the predominant form under typical pore water $\mathrm{pH}$ conditions. The hydrolysis products (represented as DOC) are treated as reactive intermediates, which are oxidized via one of the primary redox pathways (Sect. 2.3.2). The input of POC to the sediment is assumed to consist of two reactive pools and one refractory pool: $80 \%$ of the reactive organic carbon flux (67\% of the total organic carbon flux globally) is allocated to the highly reactive POC pool, which is hydrolyzed with a rate constant of $1 \mathrm{yr}^{-1}$, while the other $20 \%$ of the reactive organic carbon flux $(17 \%$ of the total organic carbon flux) is more slowly hydrolyzed, with $k=0.1$ $\mathrm{yr}^{-1}$. The reactivity, $k_{1}$, of the most reactive POC fraction is representative for phytoplankton-derived POC and falls within the typical range of $1-10 \mathrm{yr}^{-1}$ reported in the literature (e.g., Westrich and Berner, 1984; Henrichs and Doyle, 1986; Burdige, 1991). Aged or re-suspended organic matter is usually less reactive, and typical values reported in the literature range between $0.1-1 \mathrm{yr}^{-1}$ (e.g., Westrich and Berner, 1984). The third POC pool of refractory organic matter represents $16 \%$ of the total carbon pool and is assumed to be unreactive, $k=0.0 \mathrm{yr}^{-1}$ on the timescales considered here. It is not explicitly modeled, but it is included in sulfidization reactions and in $\mathrm{C}$ budget estimates.

\subsubsection{Primary redox reactions (R3-6)}

The primary redox reactions of aerobic oxidation, denitrification, iron reduction, and sulfate reduction are coupled to DOC oxidation (Table 3). For the depositional conditions considered, sulfate is never entirely exhausted when reaching the bottom of the early diagenetic zone $(x=50 \mathrm{~cm})$; hence, methanogenesis is assumed to be of minor importance in organic matter degradation. This is consistent with observations and model results for shelf sediments receiving high organic matter inputs which show that the depth scale for the onset of methanogenesis is typically on the order of a couple of meters or more (e.g., Dale et al., 2008; Regnier et al., 2011). The rates of the primary redox reactions are assumed to exhibit a first-order dependence on the concentration of DOC and a Michaelis-Menten-type dependence on the concentration of the terminal electron acceptor (Table 4). In addition, the rates of the different electron accepting pathways are scaled by their relative cell yields (Table 4). Yield values and half-saturation constants are taken from Thullner et al. (2005) (Table 5). The anaerobic processes are also noncompetitively inhibited by oxygen. The inhibition constant for denitrification is set to result in $90 \%$ inhibition when $\left[\mathrm{O}_{2}\right]=63 \mu \mathrm{M}\left(2 \mathrm{mg} \mathrm{L}^{-1}\right)$, while those for iron and sulfate reduction lead to $90 \%$ inhibition at $\left[\mathrm{O}_{2}\right]=6 \mu \mathrm{M}\left(0.2 \mathrm{mg} \mathrm{L}^{-1}\right)$. The overall DOC oxidation rate constant $k_{3}$ is common to all primary redox pathways, aerobic and anaerobic.
Table 4. Kinetic rate laws.

\begin{tabular}{|c|c|}
\hline Reaction & \\
\hline $\mathrm{R} 1=k_{\mathrm{POC} 1} \cdot[\mathrm{POC} 1]$ & \\
\hline $\mathrm{R} 2=k_{\mathrm{POC} 2} \cdot[\mathrm{POC} 2]$ & \\
\hline $\mathrm{R} 3=k_{3} \cdot\left(\frac{\left[\mathrm{O}_{2}\right]}{\left.k_{\mathrm{O}_{2}+\left[\mathrm{O}_{2}\right]}\right) \cdot\left[\mathrm{CH}_{2} \mathrm{O}\right]}\right.$ & \\
\hline $\mathrm{R} 4=k_{3} \cdot\left(\frac{Y_{\mathrm{NO}_{3}}}{Y_{\mathrm{O}_{2}}}\right) \cdot\left(\frac{\left[\mathrm{NO}_{3}\right]}{k_{\mathrm{NO}_{3}+\left[\mathrm{NO}_{3}\right]}}\right) \cdot\left[\mathrm{CH}_{2}\right.$ & $\mathrm{O}] \cdot\left(\frac{k i_{\mathrm{NO}_{3}}}{k i_{\mathrm{NO}_{3}}+\left[\mathrm{O}_{2}\right]}\right)$ \\
\hline $\mathrm{R} 5=k_{3} \cdot\left(\frac{Y_{\mathrm{Fe}}}{Y_{\mathrm{O}_{2}}}\right) \cdot\left(\frac{\left[\mathrm{Fe}(\mathrm{OH})_{3}\right]}{k_{\mathrm{Fe}}+\left[\mathrm{Fe}(\mathrm{OH})_{3}\right]}\right) \cdot\left[\mathrm{CH}_{2}\right.$ & $\mathrm{O}] \cdot\left(\frac{k i_{\mathrm{Fe}}}{k i_{\mathrm{Fe}}+\left[\mathrm{O}_{2}\right]}\right)$ \\
\hline $\mathrm{R} 6=k_{3} \cdot\left(\frac{Y_{\mathrm{SO}_{4}}}{Y_{\mathrm{O}_{2}}}\right) \cdot\left(\frac{\left[\mathrm{SO}_{4}\right]}{k_{\mathrm{SO}_{4}}+\left[\mathrm{SO}_{4}\right]}\right) \cdot\left[\mathrm{CH}_{2} \mathrm{C}\right.$ & $\cdot\left(\frac{k i_{\mathrm{SO}_{4}}}{k i_{\mathrm{SO}_{4}}+\left[\mathrm{O}_{2}\right]}\right)$ \\
\hline $\begin{array}{l}\mathrm{R} 7=k_{\mathrm{Nitrif}} \cdot\left[\mathrm{NH}_{4}^{+}\right] \cdot\left[\mathrm{O}_{2}\right] \\
\mathrm{R} 8=k_{\mathrm{FeOx}} \cdot\left[\mathrm{O}_{2}\right] \cdot\left[\mathrm{Fe}^{2+}\right] /\left[\mathrm{H}^{+}\right]^{2} \\
\mathrm{R} 9=k_{\text {SulfOx }} \cdot\left[\mathrm{O}_{2}\right] \cdot\left(\left[\mathrm{HS}^{-}\right]+\left[\mathrm{H}_{2} \mathrm{~S}\right]\right) \\
\mathrm{R} 10=k_{\mathrm{FeSOx}} \cdot[\mathrm{FeS}] \cdot\left[\mathrm{O}_{2}\right]\end{array}$ & \\
\hline $\mathrm{R} 11=k_{\mathrm{Cal}}\left(1-\Omega_{\mathrm{Cal}}\right)^{n \mathrm{Cal}}$ & $\Omega_{\mathrm{Cal}}<1$ \\
\hline $\mathrm{R} 12=k_{\text {Ara }}\left(1-\Omega_{\text {Ara }}\right)^{n \text { Ara }}$ & $\Omega_{\text {Ara }}<1$ \\
\hline $\mathrm{R} 13=k_{\mathrm{Mg}-\mathrm{cal}}\left(1-\Omega_{M g-\mathrm{cal}}\right)^{n \mathrm{Mg}-\mathrm{cal}}$ & $\Omega_{n \mathrm{Mg}-\mathrm{cal}}<1$ \\
\hline $\begin{array}{l}\mathrm{R} 14=k_{\mathrm{FeS}} \cdot\left(\frac{\left[\mathrm{Fe}^{2+}\right] \cdot\left[\mathrm{HS}^{-}\right]}{\left[\mathrm{H}^{+}\right] \cdot K S_{\mathrm{FeS}}}-1\right) \\
\mathrm{R} 15=k_{\mathrm{Pyr}} \cdot[\mathrm{FeS}] \cdot\left[\mathrm{H}_{2} \mathrm{~S}\right]\end{array}$ & $\mathrm{R} 14 \geq 0$ \\
\hline $\mathrm{R} 16=k_{\mathrm{FeCO}_{3}} \cdot\left(\frac{\left[\mathrm{Fe}^{2+}\right] \cdot\left[\mathrm{CO}_{3}^{2-}\right]}{K s_{\mathrm{FeCO}_{3}}}-1\right)$ & $\mathrm{R} 16 \geq 0$ \\
\hline $\mathrm{R} 17=k_{\mathrm{OrgS}} \cdot[$ inert-POC $] \cdot\left[\mathrm{H}_{2} \mathrm{~S}\right]$ & \\
\hline
\end{tabular}

\subsubsection{PIC dissolution (R11-13)}

The rates of dissolution of the PIC phases are computed using

$R_{\text {dissolution }}=k \cdot(1-\Omega)^{n} \cdot C$

where $C$ is the concentration of the PIC phase and $\Omega$, the saturation state, is given by

$\Omega=\left[\mathrm{Ca}^{2+}\right] \cdot\left[\mathrm{CO}_{3}^{2-}\right] / K_{\mathrm{SP}} *$ for calcite and aragonite, and

$\Omega=\left[\mathrm{Ca}^{2+}\right]^{0.85} \cdot\left[\mathrm{Mg}^{2+}\right]^{0.15} \cdot\left[\mathrm{CO}_{3}^{2-}\right] / K_{\mathrm{SP}} *$ for $15 \% \mathrm{Mg}-$ calcite.

The stoichiometric solubility products $\left(K_{\mathrm{SP}}{ }^{*}\right)$ of calcite and aragonite are calculated as a function of temperature, pressure and salinity according to Millero (1995), and the apparent solubility product of $15 \% \mathrm{Mg}$-calcite in seawater is assumed to be $21 \%$ greater than that of aragonite, based on the findings of Morse et al. (2006). The kinetic parameters $k$ and $n$ for calcite, aragonite and $15 \% \mathrm{Mg}$ calcite are obtained from Walter and Morse (1985) using Balanus, Halimeda, and Peneroplis data, respectively. The experimentally-determined rate constants $k$ are multiplied by a factor 0.1 to account for the effects of inhibitors, surface poisoning and coatings that are likely to reduce the dissolution kinetics of PIC in natural sediments.

Pore water calcium concentrations are explicitly computed, while the concentration of pore water magnesium is expected to vary little, and is kept constant at the average seawater value of $53 \mathrm{mM}$. Although pore waters may be oversaturated with respect to one or more $\mathrm{CaCO}_{3}$ phases, in 
Table 5. Selected parameters for kinetic equations.

\begin{tabular}{|c|c|c|c|}
\hline Parameter & Value & Units & Note \\
\hline$k_{\mathrm{POC} 1}$ & 1 & $\mathrm{yr}^{-1}$ & \\
\hline$k_{\mathrm{POC} 2}$ & 0.1 & $\mathrm{yr}^{-1}$ & \\
\hline$k_{\mathrm{POC} 3}$ & 0 & $\mathrm{yr}^{-1}$ & \\
\hline$k_{\mathrm{O}_{2}}$ & 20 & $\mu \mathrm{M}$ & $\mathrm{a}$ \\
\hline$k_{\mathrm{NO}_{3}}$ & 5 & $\mu \mathrm{M}$ & $\mathrm{a}$ \\
\hline$k_{\mathrm{Fe}}$ & 1 & $\mu \mathrm{mol} / \mathrm{g}$ & a \\
\hline$k_{\mathrm{SO}_{4}}$ & 1600 & $\mu \mathrm{M}$ & $\mathrm{a}$ \\
\hline$Y_{\mathrm{NO}_{3}} / Y_{\mathrm{O}_{2}}$ & 0.75 & - & $\mathrm{a}$ \\
\hline$Y_{\mathrm{Fe}} / Y_{\mathrm{O}_{2}}$ & 0.25 & - & $\mathrm{a}$ \\
\hline$Y_{\mathrm{SO}_{4}} / Y_{\mathrm{O}_{2}}$ & 0.2 & - & a \\
\hline$k i_{\mathrm{NO}_{3}}$ & 7 & $\mu \mathrm{M}$ of $\mathrm{O}_{2}$ & $\mathrm{~b}$ \\
\hline$k i_{\mathrm{Fe}}$ & 0.7 & $\mu \mathrm{M}$ of $\mathrm{O}_{2}$ & $\mathrm{~b}$ \\
\hline$k i_{\mathrm{SO}_{4}}$ & 0.7 & $\mu \mathrm{M}$ of $\mathrm{O}_{2}$ & $\mathrm{~b}$ \\
\hline$k_{\text {Nitrif }}$ & 10000 & $\mathrm{mM}^{-1} \mathrm{yr}^{-1}$ & c \\
\hline$k_{\mathrm{FeO}_{\mathrm{x}}}$ & $3.6 \cdot 10^{-6}$ & $\mathrm{mM} \mathrm{yr}^{-1}$ & d \\
\hline$k_{\mathrm{SulfO}_{\mathrm{x}}}$ & $320-320000$ & $\mathrm{mM}^{-1} \mathrm{yr}^{-1}$ & $\mathrm{e}$ \\
\hline$k_{\mathrm{Cal}}$ & 40 & $\mathrm{mM}^{-1} \mathrm{yr}^{-1}$ & $f$ \\
\hline$n_{\mathrm{Cal}}$ & 2.74 & - & $\mathrm{f}$ \\
\hline$k_{\text {Ara }}$ & 110 & $\mathrm{mM}^{-1} \mathrm{yr}^{-1}$ & $f$ \\
\hline$n_{\text {Ara }}$ & 2.43 & - & $\mathrm{f}$ \\
\hline$k_{\mathrm{Mg}-\mathrm{cal}}$ & 58 & $\mathrm{mM}^{-1} \mathrm{yr}^{-1}$ & $\mathrm{f}$ \\
\hline$n_{\mathrm{Mg}-\mathrm{cal}}$ & 3.61 & - & $\mathrm{f}$ \\
\hline$k_{\mathrm{FeS}}$ & 0.005 & $\mu \mathrm{mol} \mathrm{cm}{ }^{-3} \mathrm{yr}^{-1}$ & $\mathrm{c}$ \\
\hline$K s_{\mathrm{FeS}}$ & 6.3 & $\mu \mathrm{mol} \mathrm{cm}{ }^{-3}$ & $\mathrm{c}$ \\
\hline$k_{\text {Pyr }}$ & 60 & $\mathrm{~cm}^{3} \mu \mathrm{mol}^{-1} \mathrm{yr}^{-1}$ & g \\
\hline$k_{\text {OrgS }}$ & 0.0002 & $\mathrm{~cm}^{3} \mu \mathrm{mol}^{-1} \mathrm{yr}^{-1}$ & $\mathrm{~g}$ \\
\hline
\end{tabular}

a Thullner et al. (2005).

b Wang and Van Cappellen (1996)

c Jourabchi et al. (2005).

d Adjusted for $T$ and seawater from Stumm and Morgan (1996).

e See Sect. 2.7.1.

${ }^{\mathrm{f}}$ Recalculated from Walter and Morse (1985).

${ }^{g}$ Dale et al. (2009).

situ precipitation of non-biogenic $\mathrm{CaCO}_{3}$ in sediments is believed to be of limited importance, relative to dissolution, due to inhibition by organic compounds and magnesium (Morse and Mackenzie, 1990; Morse and Mucci, 1984). As a result, carbonate precipitation is not included in the reaction network.

\subsubsection{Other reactions}

Dissociations of $\mathrm{H}_{2} \mathrm{O}, \mathrm{H}_{3} \mathrm{BO}_{3}, \mathrm{H}_{2} \mathrm{~S}, \mathrm{H}_{2} \mathrm{CO}_{3}$ and $\mathrm{HCO}_{3}^{-}$are modeled as equilibrium reactions. The apparent equilibrium constants are adjusted for salinity, temperature and pressure according to Millero (1995). Secondary redox reactions (i.e., reoxidation reactions of reduced by-products of organic matter degradation) are also considered. The reactions included are the oxidation of ammonia, hydrogen sulfide, iron sulfides and ferrous iron by oxygen (R7-10). Iron sulfide precipitation and its conversion to pyrite are included in the reaction network, as is iron carbonate precipitation (R14-16).
Soluble ferrous iron, ammonium, and phosphate are assumed to adsorb non-specifically to solids. Specific phosphate sorption onto ferric iron phases is also modeled. The sorbed-P, sorbed-NH $\mathrm{N}_{4}^{+}$, sorbed-Fe(II) and iron(III)-sorbed-P are treated as solid-bound constituents in equilibrium with the pore water phase. Finally, refractory organic matter, which is not otherwise modeled, is assumed to react with sulfide during the process of sulfurization (R17).

\subsection{Boundary conditions}

\subsubsection{Baseline scenario}

The published estimates of global carbon (POC and PIC) deposition and burial fluxes are summarized in Table 1. In the absence of a robust regionalization of POC fluxes for the global coastal ocean, the degradable POC fluxes for the carbonate shelves, non-carbonate shelves, and banks and bays are estimated using the depth relationship for the benthic oxygen consumption of coastal sediments by Soetaert et al. (2002):

$J_{\mathrm{POC}}=40.61 \cdot \mathrm{SFD}^{-0.571}$

where $J_{\mathrm{POC}}$ is the degradable POC flux in $\mathrm{mol} \mathrm{C} \mathrm{m}^{-2} \mathrm{yr}^{-1}$. Thus, the reactive POC deposition fluxes for the $25 \mathrm{~m}, 75 \mathrm{~m}$, and $150 \mathrm{~m}$ shelf depths are $6.5,3.5$, and $2.3 \mathrm{~mol} \mathrm{C} \mathrm{m}^{-2} \mathrm{yr}^{-1}$, respectively (Table 6a) For the banks and bays environment, the reactive POC flux calculated from Eq. (8) assuming $25 \mathrm{~m}$ SFD $\left(=6.5 \mathrm{~mol} \mathrm{C} \mathrm{m}^{-2} \mathrm{yr}^{-1}\right)$ is also used. The imposed reactive POC deposition flux for reefs, $5.2 \mathrm{~mol} \mathrm{C} \mathrm{m}^{-2} \mathrm{yr}^{-1}$, corresponds to the estimated average net primary productivity of coral reef ecosystems (Hatcher, 1990). When integrated over the total surface area of the coastal ocean $(\mathrm{SFD} \leq 200 \mathrm{~m})$, the resulting global reactive POC flux estimate is $117.5 \mathrm{Tmol} \mathrm{yr}^{-1}$. This value falls within the range of published values for global coastal POC deposition flux (16 to $183 \mathrm{Tmol} \mathrm{yr}^{-1}$ ), but is somewhat higher than the average value $\left(101 \mathrm{Tmol} \mathrm{yr}^{-1}\right)$ of all the studies reported in Table 1 . In addition, estimates of the average global POC burial in coastal sediments (Table 1) indicate that global coastal sediments receive an additional $18.4 \mathrm{Tmol} \mathrm{yr}^{-1}$ of POC that is refractory on the considered time scale. The total global coastal POC deposition flux thus amounts to $136 \mathrm{Tmol} \mathrm{yr}^{-1}$. A major source of uncertainty for the DIC and alkalinity fluxes is the very limited number of studies that provide estimates of global coastal PIC deposition fluxes (Table 1). The PIC deposition fluxes are taken from Milliman and Droxler (1996), and range from $0.27 \mathrm{~mol} \mathrm{~m}^{-2} \mathrm{yr}^{-1}$ for non-carbonate shelves to $15 \mathrm{~mol} \mathrm{~m}^{-2} \mathrm{yr}^{-1}$ for coral reefs. Published estimates for the aragonite fraction of the carbonate export flux range from $10 \%$ to $50 \%$, and may be as high as $75 \%$ (Munhoven, 2007). On the shelves, we divide the PIC deposition flux into $35 \%$ aragonite and $65 \%$ calcite, based on the estimates of pelagic PIC production by Gangstø et al. (2008). For the reefs and banks and bays, PIC is divided into aragonite, calcite 
Table 6a. Boundary conditions, baseline case.

\begin{tabular}{|c|c|c|c|c|c|}
\hline Parameter & & Carbonate shelf & $\begin{array}{l}\text { Environment } \\
\text { Non-carbonate shelf }\end{array}$ & Banks and bays & Reefs \\
\hline \multicolumn{6}{|c|}{ Fluxes $\left(\mathrm{mol} \mathrm{m}^{-2} \mathrm{yr}^{-1}\right)$} \\
\hline \multirow[t]{3}{*}{ POC } & $25 \mathrm{~m}$ & 6.46 & 6.46 & 6.46 & 5.20 \\
\hline & $75 \mathrm{~m}$ & 3.45 & 3.45 & & \\
\hline & $150 \mathrm{~m}$ & 2.32 & 2.32 & & \\
\hline \multirow[t]{3}{*}{$\mathrm{Fe}(\mathrm{OH})_{3}$} & $25 \mathrm{~m}$ & 0.038 & 0.038 & 0.038 & 0.038 \\
\hline & $75 \mathrm{~m}$ & 0.036 & 0.036 & & \\
\hline & $150 \mathrm{~m}$ & 0.033 & 0.033 & & \\
\hline Calcite & & 0.39 & 0.17 & 0.65 & 1.95 \\
\hline Aragonite & & 0.21 & 0.09 & 3.15 & 9.45 \\
\hline $15 \% \mathrm{Mg}$-calcite & & 0 & 0 & 1.20 & 3.60 \\
\hline \multicolumn{6}{|c|}{ Concentrations (mM) } \\
\hline $\mathrm{O}_{2}$ & & 0.195 & 0.195 & 0.195 & 0.195 \\
\hline \multirow{3}{*}{$\mathrm{NO}_{3}^{-\mathrm{a}}$} & $25 \mathrm{~m}$ & 0.005 & 0.005 & 0.005 & 0.005 \\
\hline & $75 \mathrm{~m}$ & 0.008 & 0.008 & & \\
\hline & $150 \mathrm{~m}$ & 0.012 & 0.012 & & \\
\hline $\mathrm{SO}_{4}^{2-}$ & & 28 & 28 & 28 & 28 \\
\hline $\mathrm{H}_{2} \mathrm{PO}_{4}^{-}$ & & 0.001 & 0.001 & 0.001 & 0.001 \\
\hline $\mathrm{Ca}^{2+}$ & & 10 & 10 & 10 & 10 \\
\hline$A_{\mathrm{T}}$ & & 2.306 & 2.306 & 2.306 & 2.306 \\
\hline \multirow[t]{3}{*}{$\mathrm{DIC}^{\mathrm{a}}$} & $25 \mathrm{~m}$ & 2.022 & 2.022 & 2.022 & 2.022 \\
\hline & $75 \mathrm{~m}$ & 2.068 & 2.068 & & \\
\hline & $150 \mathrm{~m}$ & 2.138 & 2.138 & & \\
\hline \multirow[t]{3}{*}{$\mathrm{CO}_{3}^{2-}$} & $25 \mathrm{~m}$ & 0.201 & 0.201 & 0.201 & 0.215 \\
\hline & $75 \mathrm{~m}$ & 0.170 & 0.170 & & \\
\hline & $150 \mathrm{~m}$ & 0.124 & 0.124 & & \\
\hline \multirow[t]{3}{*}{ Temperature $\left({ }^{\circ} \mathrm{C}\right)$} & $25 \mathrm{~m}$ & 14.34 & 14.34 & 9.91 & 27.6 \\
\hline & $75 \mathrm{~m}$ & 11.63 & 11.63 & & \\
\hline & $150 \mathrm{~m}$ & 7.57 & 7.57 & & \\
\hline \multirow[t]{3}{*}{ pH (free scale) } & $25 \mathrm{~m}$ & 8.27 & 8.27 & 8.27 & 7.95 \\
\hline & $75 \mathrm{~m}$ & 8.19 & 8.19 & & \\
\hline & $150 \mathrm{~m}$ & 8.04 & 8.04 & & \\
\hline \multirow[t]{3}{*}{$\Omega_{\text {Aragonite }}^{\mathrm{b}}$} & $25 \mathrm{~m}$ & 2.98 & 2.98 & 2.98 & 3.19 \\
\hline & $75 \mathrm{~m}$ & 2.55 & 2.55 & & \\
\hline & $150 \mathrm{~m}$ & 2.01 & 2.01 & & \\
\hline
\end{tabular}

a Nitrate and DIC concentrations determined from SFD correlations found in GLODAP database:

$$
\begin{aligned}
& {\left[\mathrm{NO}_{3}\right](\mathrm{mM})=0.003734+0.0000584 \cdot \mathrm{SFD} \quad\left(r^{2}=0.250, p<10^{-195}\right)} \\
& {[\mathrm{DIC}](\mathrm{mM})=1.9992+0.0009220 \cdot \mathrm{SFD} \quad\left(r^{2}=0.262, p<10^{-5}\right)} \\
& \text { b } \Omega_{\text {Aragonite }} \text { calculated from Millero (1995) using pressure, salinity, and the following temperature correlation extracted from the } \\
& \text { Levitus94 database: } \\
& \text { Temp }\left({ }^{\circ} \mathrm{C}\right)=15.69-0.054 \cdot \mathrm{SFD} \quad\left(r^{2}=0.098, p<10^{-42}\right)
\end{aligned}
$$

and $15 \% \mathrm{Mg}$-calcite in the ratios $63: 13: 24$ (Land, 1967). The PIC flux in a given coastal environment is assumed to be independent of SFD (Table 6a). The Koeve (2002) relationship of the POC:PIC ratio with depth in the Atlantic Basin (POC : $\mathrm{PIC}=64.3 \cdot \mathrm{SFD}^{-0.56}$ ), when combined with the Soetaert POC deposition flux relationship (Eq. 8), re- sults in a nearly depth-independent relationship for the PIC flux $\left(=0.63 \cdot \mathrm{SFD}^{-0.011} \mathrm{~mol} \mathrm{~m}^{-2} \mathrm{yr}^{-1}\right)$, which is very close to Milliman and Droxler's (1996) estimate for PIC deposition on carbonate shelves $\left(0.60 \mathrm{~mol} \mathrm{~m}^{-2} \mathrm{yr}^{-1}\right)$. Note that our globally integrated PIC deposition flux for the coastal zone 
Table 6b. Boundary $\mathrm{pH}$ and $\Omega_{\text {Aragonite }}$ for DIC sensitivity tests.

\begin{tabular}{|c|c|c|c|c|c|}
\hline Parameter & & Carbonate shelf & $\begin{array}{l}\text { Environment } \\
\text { Non-carbonate shelf }\end{array}$ & Banks and bays & Reefs \\
\hline \multicolumn{6}{|l|}{$+2.5 \% \mathrm{DIC}$} \\
\hline \multirow[t]{3}{*}{$\mathrm{pH}$} & $25 \mathrm{~m}$ & 8.18 & 8.18 & 8.18 & 7.86 \\
\hline & $75 \mathrm{~m}$ & 8.08 & 8.08 & & \\
\hline & $150 \mathrm{~m}$ & 7.90 & 7.90 & & \\
\hline \multirow[t]{3}{*}{$\Omega_{\text {Aragonite }}$} & $25 \mathrm{~m}$ & 2.55 & 2.55 & 2.55 & 2.85 \\
\hline & $75 \mathrm{~m}$ & 2.10 & 2.10 & & \\
\hline & $150 \mathrm{~m}$ & 1.47 & 1.47 & & \\
\hline \multicolumn{6}{|l|}{$+5 \% \mathrm{DIC}$} \\
\hline \multirow[t]{3}{*}{$\mathrm{pH}$} & $25 \mathrm{~m}$ & 8.07 & 8.07 & 8.07 & 7.76 \\
\hline & $75 \mathrm{~m}$ & 7.95 & 7.95 & & \\
\hline & $150 \mathrm{~m}$ & 7.74 & 7.74 & & \\
\hline \multirow[t]{3}{*}{$\Omega_{\text {Aragonite }}{ }^{\mathrm{a}}$} & $25 \mathrm{~m}$ & 2.07 & 2.07 & 2.07 & 2.34 \\
\hline & $75 \mathrm{~m}$ & 1.63 & 1.63 & & \\
\hline & $150 \mathrm{~m}$ & 1.05 & 1.05 & & \\
\hline \multicolumn{6}{|c|}{$\begin{array}{l}\text { a } \Omega_{\text {Aragonite }} \text { calculated from Millero (1995) using pressure, salinity, and the following temperature correlation extracted from } \\
\text { the Levitus } 94 \text { database: }\end{array}$} \\
\hline
\end{tabular}

is also in agreement with the value used by Andersson et al. (2005; Table 1).

Raiswell (2006) estimated the global delivery of highly reactive iron to the shelves to be $53 \mathrm{Tg} \mathrm{yr}^{-1}$, primarily from rivers, atmospheric dust, and diagenetic recycling. Dividing by the shelf area, this gives an average deposition flux of $0.036 \mathrm{~mol} \mathrm{Fe} \mathrm{m}^{-2} \mathrm{yr}^{-1}$, which we scale with the sediment burial rate in order to estimate the reactive iron deposition in the various environments and water depth ranges (Table 6a).

Bottom water temperature, oxygen concentration, and nitrate concentration are extracted from the $1^{\circ}$ dataset of the Levitus94 database. For each latitude and longitude in the dataset, the deepest water depth with data available is taken as representative of bottom water, and the corresponding (temperature, oxygen or nitrate) values are inferred to be the bottom water values. Over the 0-200 m SFD range, no significant relationship exists between bottom water $\left[\mathrm{O}_{2}\right]$ and water depth $(p>0.05)$; therefore, the average oxygen concentration $(0.195 \mathrm{mM})$ is used. Nitrate and temperature are both water-depth-dependent (Table 6a). The average bottom water temperature is used along with pressure to calculate $K_{\mathrm{SP}}^{*}$ values for aragonite and calcite (Millero, 1995) and the apparent equilibrium constants for the dissociation of weak acids. The global average temperature for coral reefs, $27.6^{\circ} \mathrm{C}$ (Kleypas et al., 2005), is used as bottom water value for the reefs.

Analysis of the GLODAP database for stations with seafloor depths $\leq 200 \mathrm{~m}$ (accessed from http://cdiac.ornl.gov/ftp/oceans/GLODAP_bottle_files/) indicates that dissolved inorganic carbon (DIC) also varies with SFD. In contrast, there is no significant correlation between salinity or alkalinity and seafloor depth $(p>0.05)$, so the average values of 34.64 (psu) and $2.306 \mathrm{meq} \mathrm{L}^{-1}$ are used. The bottom water alkalinity and DIC concentrations are used to calculate $\mathrm{pH}$ and partitioning of the aqueous carbonate species $\left(\mathrm{H}_{2} \mathrm{CO}_{3}{ }^{*} / \mathrm{HCO}_{3}^{-} / \mathrm{CO}_{3}^{2-}\right)$, using the apparent equilibrium dissociation constants adjusted for depth, salinity and temperature (Millero, 1995). Table 6a presents the alkalinity, $\mathrm{DIC}, \mathrm{pH},\left[\mathrm{CO}_{3}^{2-}\right]$, and aragonite saturation imposed as bottom water boundary conditions.

The total dissolved boron concentration is estimated from salinity according to Millero (1995). The concentrations of $\mathrm{SO}_{4}^{2-}, \mathrm{Ca}^{2+}$ and $\mathrm{Mg}^{2+}$ at the sediment-water interface are set to 28,10 , and $53 \mathrm{mM}$, respectively, while bottom water $\left[\mathrm{H}_{2} \mathrm{PO}_{4}^{-}\right]$is assumed to be $0.001 \mathrm{mM}$. The concentrations of $\mathrm{H}_{2} \mathrm{~S}, \mathrm{HS}^{-}, \mathrm{NH}_{4}^{+}, \mathrm{Fe}^{2+}$ at the seafloor are assumed to be zero.

\subsection{Benthic DIC and alkalinity flux}

Because the DIC buried with pore waters is very small $(<1 \%)$, and in situ $\mathrm{CaCO}_{3}$ precipitation and $\mathrm{FeCO}_{3}$ precipitation are predicted to be minimal, the benthic DIC efflux is essentially equal to the sum of the depth-integrated rates of POC oxidation and PIC dissolution. For the alkalinity flux the situation is more complicated and can be analyzed as follows. 
Assuming steady state, the alkalinity flux from the sediments, $J_{\text {Alk_out }}$, can be computed as

$J_{\text {Alk_out }}=\mathrm{Alk}_{\text {redox }}+\mathrm{Alk}_{\text {PIC diss }}-\mathrm{Alk}_{\text {burial }}-2\left(\mathrm{FeS}, \mathrm{FeS}_{2}\right.$, and $\left.\mathrm{FeCO}_{3}, \mathrm{OrgS}\right)_{\text {burial }}$,

where $\mathrm{Alk}_{\text {redox }}$ and AlkPIC diss represent alkalinity generation by the (primary and secondary) redox reactions and carbonate dissolution, respectively (see Table 3 for individual con-

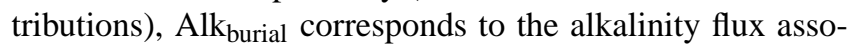
ciated with pore water burial, and the last term on the righthand side is the burial flux of reduced $\mathrm{Fe}^{2+}$ minerals and organic sulfur (see below). For the baseline simulations, the fraction of generated alkalinity that is buried is small and ranges from $1.3 \%$ at $25 \mathrm{~m}$ water depth to $2 \%$ at $150 \mathrm{~m}$ water depth.

The effect of removal of FeS by burial on the pore water alkalinity balance can be expressed by writing a net reaction for $\mathrm{FeS}$ generation, which combines sulfate and iron reduction (see Carignan and Tessier, 1988):

$9 \mathrm{CH}_{2} \mathrm{O}+4 \mathrm{Fe}(\mathrm{OH})_{3}+4 \mathrm{SO}_{4}^{2-}+8 \mathrm{H}^{+} \rightarrow 4 \mathrm{FeS}+19 \mathrm{H}_{2} \mathrm{O}+9 \mathrm{CO}_{2}$

Similarly, the net effects of burial of $\mathrm{FeS}_{2}, \mathrm{FeCO}_{3}$, and $\mathrm{OrgS}$ can be expressed by combining reactions (R5), (R6), and (R14-R17):

$$
\begin{gathered}
17 \mathrm{CH}_{2} \mathrm{O}+4 \mathrm{Fe}(\mathrm{OH})_{3}+8 \mathrm{SO}_{4}^{2-}+16 \mathrm{H}^{+} \rightarrow \\
4 \mathrm{FeS}_{2}+17 \mathrm{CO}_{2}+4 \mathrm{H}_{2}+27 \mathrm{H}_{2} \mathrm{O}
\end{gathered}
$$

$\mathrm{CH}_{2} \mathrm{O}+4 \mathrm{Fe}(\mathrm{OH})_{3}+3 \mathrm{CO}_{2} \rightarrow 4 \mathrm{FeCO}_{3}+7 \mathrm{H}_{2} \mathrm{O}$

$2 \mathrm{CH}_{2} \mathrm{O}+$ inert-POC $+\mathrm{SO}_{4}^{2-}+2 \mathrm{H}^{+} \rightarrow 2 \mathrm{CO}_{2}+$ orgS $+2 \mathrm{H}_{2} \mathrm{O}$

As can be seen from these reaction formulas, burial of reduced iron and sulfur species results in a net production of alkalinity of 4 equivalents per mol $\mathrm{FeS}_{2}, 2$ equivalents per mol FeS, 2 equivalents per mol organically bound S(-II), and 0 equivalents per mol $\mathrm{FeCO}_{3}$.

Although the above reactions generate alkalinity, it is important to note that the burial of reduced compounds actually lowers the alkalinity generation compared to that predicted from iron reduction and sulfate reduction alone. For example, in generating $1 \mathrm{~mol}$ of FeS, 2 moles of organic carbon are oxidized via sulfate reduction, and $\frac{1}{4}$ via iron reduction (Eq. 10). If we would only consider the primary redox reactions, iron reduction and sulfate reduction would each produce 2 equivalents of alkalinity ( $\frac{1}{4} \mathrm{R} 5$ and $2 \mathrm{R} 6$ ), that is, significantly more than the 2 equivalents predicted by $\mathrm{R} 12$. Since the alkalinity generation by the primary redox reactions is already included in $\mathrm{Alk}_{\text {redox }}$, for the purpose of alkalinity accounting (in terms of the contribution of individual reactions to the flux through the SWI), the burial of reduced iron species $\left(\mathrm{FeS}, \mathrm{FeS}_{2}\right.$, and $\left.\mathrm{FeCO}_{3}\right)$ actually decreases alkalinity generation by 2 equivalents per $\mathrm{mol} \mathrm{Fe}^{2+}$ mineral buried (compared to the predicted alkalinity generation in the absence of $\mathrm{Fe}^{2+}$ mineral burial) and this contribution is thus a sink term in Eq. (9).

A major fraction of the alkalinity efflux $J_{\text {Alk_out }}$ is under the form of reduced solute species $\left(\mathrm{HS}^{-}, \mathrm{H}_{2} \mathrm{~S}, \mathrm{NH}_{4}^{+}\right.$ and $\mathrm{Fe}^{2+}$ ), which tend to be short-lived when released in oxygenated waters. Rapid reoxidation of $\mathrm{Fe}^{2+}$ near burrow walls and at the water-sediment interface is accounted for by imposing a strongly reduced bioirrigation coefficient (Sect. 2.2). Some of the dissolved iron escaping coastal sediments may be exported laterally to the open ocean, where it may fuel biological productivity (e.g., Dulaiova et al., 2009). In addition, the fate of the benthic ammonium flux in the water column (i.e., nitrification, export, assimilation by phytoplankton as ammonium or nitrate, burial in the sediment) will have an important influence on the coastal ocean alkalinity budget. However, because of the complexity of the problem, a holistic assessment of the influence of the benthic ammonium flux on coastal ocean alkalinity would require a coupled pelagic-benthic model. Our diagenetic model approach can only provide the flux of alkalinity through the sedimentwater interface. Based on these considerations, we hypothesize that $J_{\text {Alk_out }}$ calculated with Eq. (9) overestimates the irreversible source of benthic alkalinity to the coastal ocean alkalinity primarily because of the re-oxidation of free sulfide at or near the water-sediment interface, a very rapid reaction (Kaplan et al., 1963; Jørgensen and Fenchel, 1974; Jørgensen, 1978). Because the alkalinity generated when 1 mol of sulfide is produced via sulfate reduction exactly cancels that consumed when $1 \mathrm{~mol}$ of sulfide is re-oxidized to sulfate (Table 3), combined sulfate reduction and sulfide oxidation potentially has no effect on water column alkalinity. Although some reduced sulfur can be assimilated, volatilized or exported off-shelf (Chen and Wang, 1999; Chen, 2002; Thomas et al., 2009), it is likely that most of the modelpredicted efflux of free sulfide is efficiently oxidized at or near the water-sediment interface. Therefore, we propose that correcting $J_{\text {Alk_out }}$ for the oxidation of $\mathrm{H}_{2} \mathrm{~S}$ and $\mathrm{HS}^{-}$ provides a more realistic measure for the effective benthic alkalinity flux $J_{\mathrm{Alk}}{ }^{*}$ to the coastal ocean:

$J_{\mathrm{Alk}}{ }^{*}=J_{\text {Alk_out }}-2 \cdot\left(\mathrm{HS}^{-}+\mathrm{H}_{2} \mathrm{~S}\right)_{\text {out }}$,

where the sulfide efflux ( $\mathrm{HS}^{-}+\mathrm{H}_{2} \mathrm{~S}$ ) out is calculated directly from the model computed diffusion and bioirrigation fluxes of the two sulfide species. Alternatively, $\left(\mathrm{HS}^{-}+\mathrm{H}_{2} \mathrm{~S}\right)_{\text {out }}$ can also be obtained from the sulfide mass balance:

$$
\begin{aligned}
\left(\mathrm{HS}^{-}+\mathrm{H}_{2} \mathrm{~S}\right)_{\text {out }}= & \frac{1}{2} \mathrm{SO}_{4}^{2-} \text { reduction }-\frac{1}{2} \mathrm{HS}^{-} \text {oxidation }-\mathrm{FeS} \text { precipitation } \\
& - \text { pyritization }- \text { sulfidization } \\
& -\left(\mathrm{HS}^{-}+\mathrm{H}_{2} \mathrm{~S}\right)_{\text {burial }}
\end{aligned}
$$

where

$\mathrm{FeS}$ precipitation $=\mathrm{FeS}_{\text {burial }}+$ pyritization $+\frac{1}{2} \mathrm{FeS}$ oxidation. 
Combining Eqs. (9), (14), (15) and (16), and using the stoichiometries in Table 3, $J_{\mathrm{Alk}}{ }^{*}$ can then be expressed as

$$
\begin{aligned}
J_{\mathrm{Alk}}{ }^{*}= & 8(\text { net Fe reduction })+0.14 \cdot \text { ammonification }+0.8 \cdot \text { denitrification } \\
& - \text { nitrification }+2(\mathrm{PIC} \text { dissolution })-\mathrm{Alk}_{\text {burial }}+2\left(\mathrm{HS}^{-}+\mathrm{H}_{2} \mathrm{~S}\right. \\
& \left.+ \text { orgS }-\mathrm{FeCO}_{3}+\mathrm{FeS}_{2}\right)_{\text {burial }} .
\end{aligned}
$$

While Eqs. (14) and (17) are equivalent expressions of $J_{\mathrm{Alk}}{ }^{*}$, the latter equation provides additional insight into the processes that contribute to $J_{\mathrm{Alk}}{ }^{*}$.

\subsection{Sensitivity study}

Using the $75 \mathrm{~m}$ water depth carbonate shelf environment as an example, we analyze the sensitivity of benthic DIC and alkalinity production and fluxes to a number of the "internal" model parameters.

\subsubsection{Sulfur cycle}

The fate of sulfide produced in the process of organoclastic sulfate reduction exerts an important influence on the saturation state of pore waters with respect to carbonates. Sulfide oxidation by oxygen is often the main driver for shallow subsurface carbonate dissolution (Luff and Wallmann, 2003). Yet, published values for sulfide oxidation rate constants range widely. For example, the $k_{\text {SulfOx }}$ value used by Wang and Van Cappellen (1996) is three orders of magnitude greater than the value of Jourabchi et al. (2005), which we use in the baseline scenario. We therefore test $k_{\mathrm{SulfO}_{\mathrm{x}}}$ values equal to $10 \times, 100 \times$, and $1000 \times$ the baseline value. In addition, we explore the effect of $0.1 \times$ the baseline sulfide bioirrigation coefficient.

\subsubsection{Iron cycle}

Dissimilatory iron reduction generates 8 eq alkalinity per mol of $\mathrm{Fe}^{3+}$ reduced (Table 3), though the effect of iron reduction on sediment alkalinity generation depends on the fate of reduced species, notably $\mathrm{Fe}^{2+}$ (see Sect. 2.5). The benthic alkalinity flux will therefore be influenced by the availability of reactive iron in the sediment. However, there is considerable uncertainty in the amount of reactive iron deposition on coastal sediments. While Poulton and Raiswell (2002) estimated that $388 \mathrm{Tg} \mathrm{yr}^{-1}$ of reactive iron are discharged from rivers globally, we use the more recent estimate of Raiswell (2006) of $52 \mathrm{Tg} \mathrm{yr}^{-1}$ for the combined inputs from rivers $(67 \%)$, atmospheric dust $(17 \%)$, diagenetic recycling (10\%), coastal erosion (4\%), and glaciers (2\%). The resulting average reactive $\mathrm{Fe}(\mathrm{III})$ deposition flux is approximately $70 \%$ lower than that used by Thullner et al. (2009) for their $100 \mathrm{~m}$ water depth simulations. Here we test the effect of a doubling of the iron (oxy)hydroxide deposition flux on the DIC and alkalinity fluxes in coastal sediments. In addition, simulations are run with $10 \times$ the baseline FeS precipitation rate constant.

\subsection{Global change scenarios}

\subsubsection{Global coastal ocean productivity}

Over the past decades, human activity has significantly accelerated the supply of land-derived nutrients to the coastal ocean. As a result, nearshore areas experience increase eutrophication with potentially important implications for the global carbon cycling (e.g., Cloern, 2001; Turner and Rabalais, 2003; Mackenzie et al., 2005).

For each environment, we tested a range of reactive POC fluxes from $12.5 \%$ to $150 \%$ of the baseline value, to span the range of published global coastal POC flux values and gain insights into the response of DIC and alkalinity production and fluxes to organic matter fluxes and eutrophication. The sensitivity analysis then focuses on the effects of variations in the POC deposition flux on the partitioning of organic matter degradation between the different oxidation pathways, the fate of PIC, and benthic DIC and $A_{\mathrm{T}}$ fluxes.

\subsubsection{Acidification scenario}

Ocean acidification is likely to affect biocalcification rates (Andersson et al., 2011; Orr et al., 2005) thereby potentially affecting the PIC depositional flux to coastal sediments. Because the non-carbonate shelf boundary conditions are identical to those of the carbonate shelves, except for the $56 \%$ lower PIC deposition flux, we use the baseline non-carbonate shelf model outputs to represent the carbonate shelves under decreased PIC deposition. Decreased PIC deposition in the non-carbonate shelves, reefs, and banks and bays is modeled by imposing a decrease of the PIC deposition flux by $44 \%$ relative to the baseline PIC flux. This decrease in PIC deposition approximately equals the decrease predicted by the year 2100 for the most extreme case considered by Andersson et al. (2005).

The effect of increasing seawater DIC due to increasing atmospheric $\mathrm{CO}_{2}$ is also tested. Alkalinity and temperature are kept constant, and the carbonate system is recalculated for $2.5 \%$ and $5 \%$ increases in DIC, leading to a drop in bottom water $\mathrm{pH}$ of 0.11 and $0.24 \mathrm{pH}$ units, respectively (Table $6 \mathrm{~b}$ ). In all cases, the water column remains oversaturated with respect to the carbonate mineral phases considered.

Although modeling water column carbonate chemistry and ocean-atmosphere $\mathrm{CO}_{2}$ exchange is beyond the scope of this work, it is useful to estimate the magnitude of the atmospheric $\mathrm{CO}_{2}$ increase that is needed to produce the imposed changes in the bottom water carbonate system. If the coastal surface water alkalinity, the differences in temperature and DIC between bottom and surface waters, and the surface water undersaturation with respect to atmospheric $\mathrm{CO}_{2}$ observed in the GLODAP dataset all remain constant, the baseline, $+2.5 \%$, and $+5 \%$ bottom water DIC scenarios correspond to 369,495 , and $686 \mathrm{ppm}$ atmospheric $\mathrm{CO}_{2}$, respectively. These values are close to the atmospheric $\mathrm{CO}_{2}$ 


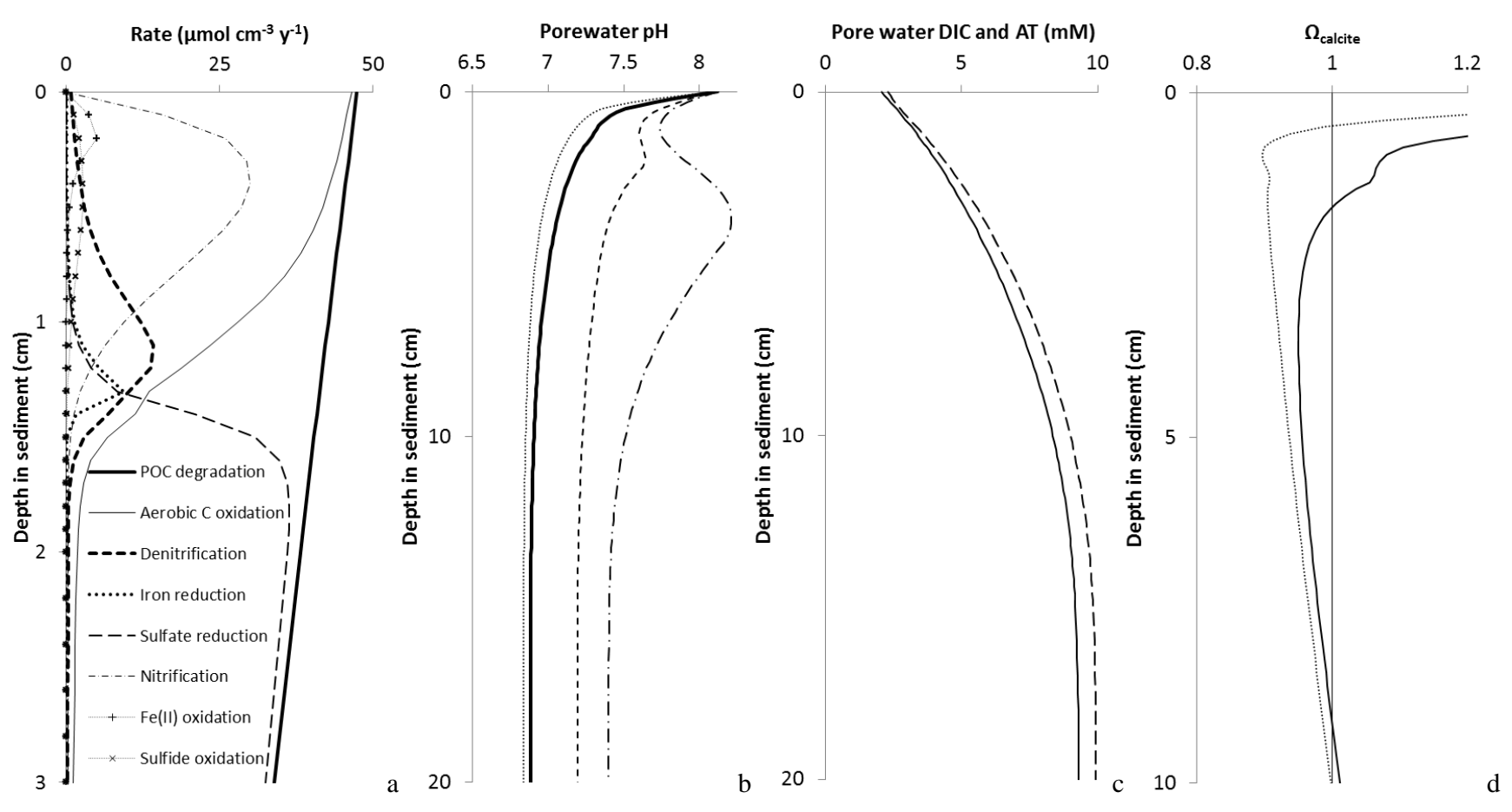

Fig. 1. (a) Redox reactions depth profiles, $75 \mathrm{~m}$ carbonate shelf, baseline POC flux. Total POC oxidation (-), aerobic C oxidation (-), denitrification (---), iron reduction (.....), sulfate reduction (---), nitrification $(-\cdot-\cdot)$, Fe(II) oxidation (+), and sulfide oxidation (-X*). (b) Porewater $\mathrm{pH}$ depth profile, $75 \mathrm{~m}$ carbonate shelf. $25 \%(-\cdot-\cdot), 50 \%(--), 100 \%$ (-), and $150 \%$ (....) of baseline POC flux. (c) Porewater DIC and $A_{\mathrm{T}}$, baseline POC flux, $75 \mathrm{~m}$ carbonate shelf. $A_{\mathrm{T}}(---)$ and DIC (-). (d) Calcite saturation state $(\Omega)$ depth profile, $75 \mathrm{~m}$ carbonate shelf, baseline POC flux. Baseline seawater DIC (-) and ocean acidification scenario +5\% DIC (....).

concentrations predicted for the years 2000, 2050, and 2100, respectively, for the IS92a scenario (Joos et al., 1999).

\section{Results and discussion}

\subsection{DIC and alkalinity production and fluxes in the global coastal ocean: baseline scenario}

In Sects. 3.1.1-3.1.4, we quantify DIC and alkalinity generation within the sediment due to POC oxidation and PIC dissolution; in Sect. 3.1.5, we quantify their fluxes through the sediment-water interface.

\subsubsection{Organic matter degradation: DIC production}

The baseline simulations reproduce the typical vertical redox stratification observed in aquatic sediments, with aerobic carbon oxidation occurring nearest the water-sediment interface, followed by denitrification, iron reduction, and sulfate reduction (Fig. 1a). In the early diagenetic scenarios considered here, the degradable POC is consumed within the top $20 \mathrm{~cm}$ of sediment, and pore water sulfate never drops below $10 \mathrm{mM}$. The distribution of organic carbon oxidation over the various primary redox pathways is shown in Fig. 2a, for the baseline scenario simulations. Because for each mole of organic $\mathrm{C}$ oxidized $1 \mathrm{~mol}$ of DIC is produced, the figure also shows the contribution of the primary respiration processes to DIC generation.

The total DIC production is determined by the imposed reactive POC deposition fluxes, which range from $6.46 \mathrm{~mol} \mathrm{C} \mathrm{m}^{-2} \mathrm{yr}^{-1}$ for the banks and bays and the $25 \mathrm{~m}$ water depth shelf environments to $2.32 \mathrm{~mol} \mathrm{C} \mathrm{m}^{-2} \mathrm{yr}^{-1}$ for the $150 \mathrm{~m}$ shelf depth. Aerobic respiration accounts for $12 \%$ ( $25 \mathrm{~m}$ water depth shelves, and banks and bays) to $16 \%$ ( $150 \mathrm{~m}$ water depth shelves) of total organic $\mathrm{C}$ oxidation, while denitrification and iron reduction account for $2-5 \%$ and $0.3-0.7 \%$ of carbon oxidation, respectively. Sulfate reduction is the main respiratory pathway. For the $25 \mathrm{~m}$ water depth shelves and the banks and bays, sulfate reduction explains $85 \%$ of organic $\mathrm{C}$ oxidation, while at $150 \mathrm{~m}$ water depth, $77 \%$ of $\mathrm{C}$ oxidation is coupled to sulfate reduction.

\subsubsection{Carbonate dissolution: DIC production}

Carbonate mineral dissolution in shallow sediments is driven by POC mineralization and the resulting $\mathrm{CO}_{2}$ production (Morse and Mackenzie, 1990). The model simulations predict that $\mathrm{pH}$ decreases with depth below the sediment-water interface as a result of $\mathrm{CO}_{2}$ generation. Figure $1 \mathrm{~b}$ illustrates the evolution of $\mathrm{pH}$ with depth for the $75 \mathrm{~m}$ carbonate shelf environment: $\mathrm{pH}$ decreases monotonically from 8.1 at the SWI to 6.8 at depths greater than $15 \mathrm{~cm}$. This baseline $\mathrm{pH}$ 


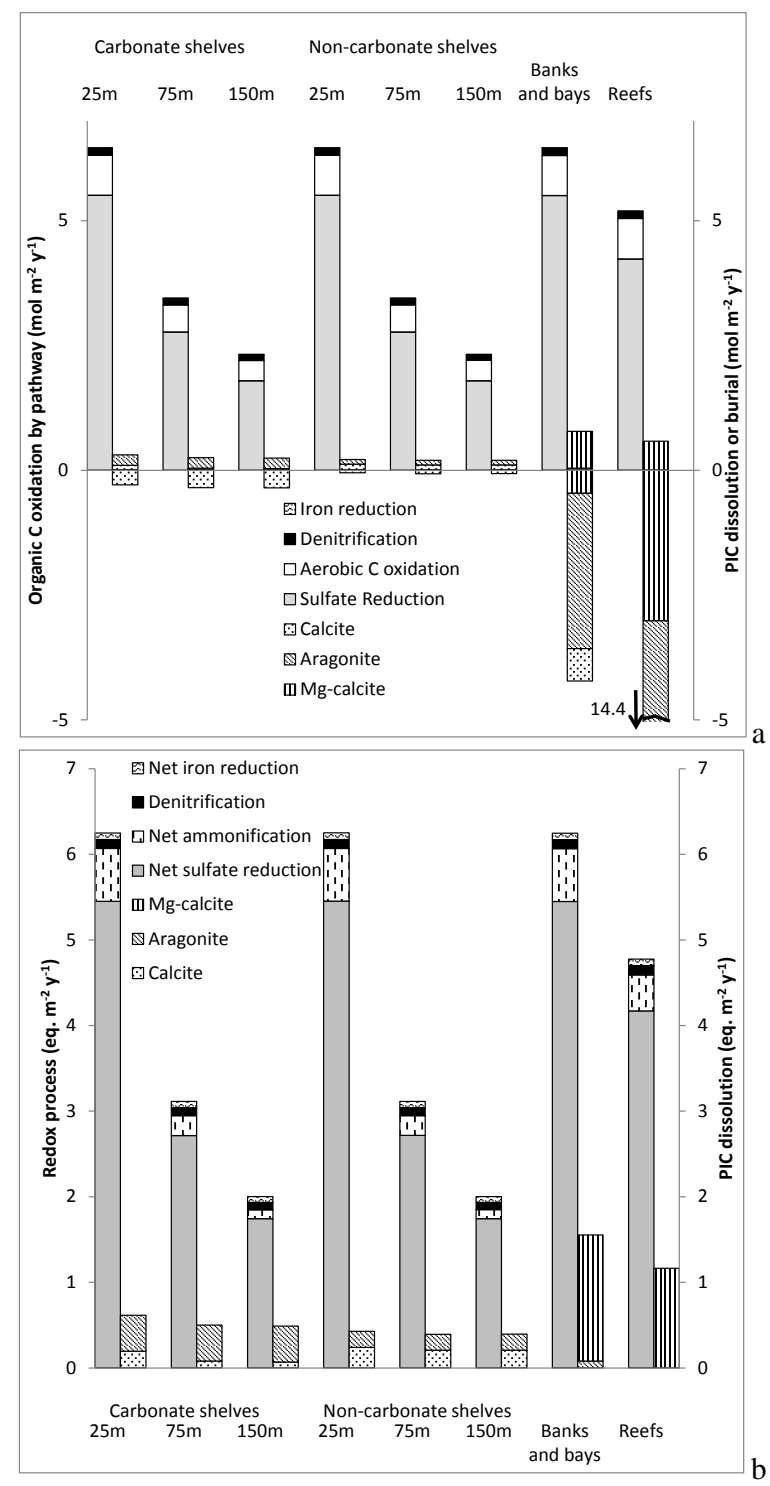

Fig. 2. Processes generating DIC (a) and alkalinity (b) for the banks and bays, reef, carbonate shelf, and non-carbonate shelf environments. Baseline POC flux. Processes contributing $<1 \%$ to the total are not shown.

profile can be considered representative except simulations with significantly lower POC flux where $\mathrm{pH}$ reaches a local minimum below the SWI before peaking again at a few $\mathrm{cm}$ (pH rise due to iron reduction), and finally decreasing at depth (Fig. 1b). Thus, the model yields pH values well within the $\mathrm{pH}$ range observed in coastal marine sediments. Porewater alkalinity and dissolved inorganic carbon increase with depth (Fig. 1c). Despite this increase in DIC, $\left[\mathrm{CO}_{3}^{2-}\right]$ decreases because of the decrease in $\mathrm{pH}$, resulting in a decrease in $\mathrm{CaCO}_{3}$ saturation with depth in the sediment (Fig. 1d). The point where the pore water becomes undersaturated depends on the imposed boundary conditions. The relationship between POC oxidation and PIC dissolution is further com- plicated by the presence of three $\mathrm{CaCO}_{3}$ phases with differing solubilities and dissolution kinetics. As a result, no simple relationship emerges between the PIC: POC deposition ratio and PIC dissolution: each PIC phase needs to be considered separately. Overall, the sediment depth-resolved saturation state calculations are in line with the observations of Mucci et al. (2000) who reported a rapid decrease with depth of pore water saturation state with respect to aragonite, and occasionally with respect to calcite, in continental sediments of the eastern Canadian continental margin.

For the shallow environments containing $\mathrm{Mg}$-calcite (reefs and banks and bays), dissolution of this most soluble phase begins when the POC deposition flux exceeds $\sim 0.8 \mathrm{~mol} \mathrm{C} \mathrm{m}^{-2} \mathrm{yr}^{-1}$ (Fig. 3a). Beyond this point, the depthintegrated dissolution rate of $\mathrm{Mg}$ calcite increases linearly with additional POC deposition. For the shelves (which do not include $\mathrm{Mg}$-calcite), aragonite will begin to dissolve when the POC flux exceeds $\sim 0.5 \mathrm{~mol} \mathrm{C} \mathrm{m}^{-2} \mathrm{yr}^{-1}$, and then increase linearly with additional POC deposition, until all aragonite is exhausted on the carbonate and non-carbonate shelves; at this point the dissolution flux equals the imposed deposition flux of aragonite (Fig. 3b). For the reefs, there is minimal aragonite dissolution, as the sediment is buffered by Mg-calcite dissolution, which commences when the POC flux is greater than $0.8 \mathrm{~mol} \mathrm{C} \mathrm{m}^{-2} \mathrm{yr}^{-1}$. In the banks and bays environment, some aragonite dissolution is observed at the highest POC fluxes. Calcite dissolution is not observed for the reefs or banks and bays environments (Fig. 3c). While calcite is never completely dissolved on the carbonate shelves, complete dissolution occurs at the highest POC loadings for the $25 \mathrm{~m}$ water depth non-carbonate shelves.

Assuming a dry sediment density of $2.5 \mathrm{~g} \mathrm{~cm}^{-3}$, the model-predicted average PIC content of coastal sediments at $20 \mathrm{~cm}$ below the SWI (the depth by which the vast majority of reactive POC is degraded) is $0.4 \%$ for the noncarbonate shelves, $2.2 \%$ for the carbonate shelves, $26 \%$ in banks and bays, and $90 \%$ below reefs. The corresponding PIC contents are $0,0.26,3.1$, and $11 \mathrm{wt} \% \mathrm{C}$, respectively. In the baseline simulations, on average $45 \%$ of the deposited PIC is dissolved on carbonate shelves, $76 \%$ on non-carbonate shelves, $16 \%$ in banks and bays, and $4 \%$ in reef environments (Fig. 2a). Although the model assumes that PIC deposition does not depend on SFD within the coastal zone (Sect. 2.4.1), the bottom water carbonate saturation state $(\Omega)$ decreases with water depth while metabolically induced PIC dissolution also decreases with water depth, due to decreased POC deposition flux. The net result is that the model-predicted PIC concentrations are higher at greater seafloor depth on the shelves $\left(0.22 \% \mathrm{C}_{\text {inorg }}\right.$ at $25 \mathrm{~m}$ water depth vs. $0.30 \% \mathrm{C}_{\text {inorg }}$ at $150 \mathrm{~m}$ water depth for carbonate shelves), because of lower dissolution. For comparison, Mucci et al. (2000) report PIC concentrations on the order of $0.4-0.9 \mathrm{wt} \% \mathrm{C}_{\text {inorg }}$ in sediments accumulating between 230 to $360 \mathrm{~m}$ water depth on the continental shelf of eastern Canada. 
The production of DIC from PIC dissolution is significantly smaller than that due to POC mineralization (Fig. 2a). Carbonate dissolution represents $3.2-7.8 \%$ of the total DIC generated in non-carbonate shelf sediments (depending on SFD), $4.6-9.5 \%$ of total DIC production in carbonate shelf sediments, and $11 \%$ and $10 \%$ of DIC production in sediments of banks and bays and reefs, respectively.

\subsubsection{Organic matter degradation: alkalinity production}

Except for organic carbon oxidation coupled to aerobic respiration, the primary redox reactions generate alkalinity, while secondary redox reactions generally consume alkalinity (Table 3). On a per mole basis, oxidation of reduced iron (R8 in Table 3) consumes exactly the amount of alkalinity generated by iron reduction (R5); hence, in Fig. $2 b$ net iron reduction $(=\mathrm{R} 5-\mathrm{R} 8)$ is reported. We further define net sulfate reduction as sulfate reduction (R6) minus sulfide oxidation (R9) and $\mathrm{FeS}$ oxidation (R10). Although the latter reaction (R10) by itself does not consume alkalinity (Table 3 ), precipitation of $\mathrm{FeS}$ (R14) results in the production of 2 fewer alkalinity equivalents than would be expected from the iron and sulfate reduction reactions (see Sect. 2.5); therefore, $\mathrm{HS}^{-}$that combines with $\mathrm{Fe}^{2+}$, but which is subsequently re-oxidized to sulfate, consumes the same amount of alkalinity as if it were oxidized directly from the aqueous form (R9).

The effect of the nitrogen cycle on sediment alkalinity production is slightly more complicated. First, denitrification (R4) is a source of alkalinity. Second, ammonification during hydrolysis (Sect. 2.3.1) also generates alkalinity, (R1, $\mathrm{R} 2$ ) but, if followed by nitrification (R7), the coupled process becomes a net alkalinity sink. That is, if all $\mathrm{NH}_{4}^{+}$generated by ammonification is nitrified, 0.16 equivalent of alkalinity would be consumed per mole of POC hydrolyzed. In what follows, we therefore opt to separately report the alkalinity production due to net ammonification (ammonification - nitrification) and denitrification.

Net sulfate reduction is by far the greatest contributor (70-82\%) of in situ alkalinity generation (Fig. 2b). Net ammonification contributes $4.2-9.0 \%$ of the overall alkalinity, while denitrification yields $1.4-3.6 \%$ and net iron reduction $1.0-2.8 \%$. The relative contribution of sulfate reduction is greatest at the shallow water depths, where reactive POC deposition is higher. Ammonification is directly proportional to the POC deposition flux, decreasing with water depth. Despite the fact that the percentage of $\mathrm{C}$ oxidized via nitrate reduction increases with water depth, the overall amount of denitrification decreases along with the decrease in reactive POC flux with depth. Alkalinity production by net iron reduction is dictated by the reactive iron influx, which we scale to sedimentation rate, and hence it decreases (in absolute value) with water depth.

\subsubsection{Carbonate dissolution: alkalinity production}

Carbonate mineral dissolution is the second largest contributor after sulfate reduction to in situ alkalinity generation (Fig. 2b). It accounts for 6 to $20 \%$ of alkalinity production. It is highest in sediments from reefs and banks and bays, the two environments for which $\mathrm{Mg}$-calcite is included as a carbonate mineral phase. In the baseline scenario, aragonite dissolves completely in sediments of carbonate and noncarbonate shelves (Fig. 2a). Depending on seafloor depth, dissolution consumes $60-70 \%$ of deposited calcite on the non-carbonate shelves, and 8-25\% on the carbonate shelves. In sediments from banks and bays, $61 \%$ of deposited $\mathrm{Mg}$ calcite dissolves, $1 \%$ of deposited aragonite, and none of the deposited calcite. For sediments accumulating below reefs, only $\mathrm{Mg}$-calcite (16\%) dissolves (Fig. 2a).

Dissolution of 1 mol PIC generates 2 equivalents of alkalinity, which are added to the alkalinity generated by the redox reactions. PIC dissolution accounts for 9 to $19 \%$ of alkalinity generated in carbonate shelf sediments (depending on water depth), 6 to $16 \%$ in non-carbonate shelf sediments, and $19 \%$ in sediments from banks and bays and reef environments (Fig. 2b).

\subsubsection{Global coastal flux estimate}

The fluxes for the various coastal environments defined by Milliman et al. (1996) are multiplied by their corresponding surface areas to estimate first-order areal-integrated coastal DIC fluxes (Table 7, Fig. 4). Because of their large areal extent, non-carbonate shelves contribute most (55\%) to global DIC generation. Carbonate shelves, banks and bays, and reef environments contribute $37 \%, 5 \%$, and $3 \%$, respectively, to global coastal benthic DIC release (Table 7, Fig. 4a). As discussed earlier, benthic DIC fluxes are largely sustained by benthic organic carbon degradation, while carbonate dissolution only contributes a small fraction. Global organic carbon oxidation in coastal sediments amounts to $117 \mathrm{Tmol} \mathrm{yr}^{-1}$, of which $56 \%$ occurs on non-carbonate shelves, $37 \%$ on carbonate shelves, $4 \%$ in banks and bays, and $3 \%$ in reef environments. Results show the large dominance of anaerobic decomposition of POC for DIC production and fluxes. Sulfate reduction accounts for $83 \%$ of reactive POC (excluding the non-reactive fraction) oxidized on the shelves, $85 \%$ in banks and bays, and $81 \%$ of organic $\mathrm{C}$ oxidation in reefs. Globally (i.e., all environments combined), $83 \%$ of organic $\mathrm{C}$ oxidation in coastal sediments is coupled to sulfate reduction. While the inferred dominant role of sulfate reduction contrasts with lower contributions proposed in earlier work (Jørgensen, 1982; Canfield, 1989; Archer et al., 2002), it is in line with the more recent work of Canfield (2005) and Thullner et al. (2009). The baseline simulations further yield global contributions to organic carbon oxidation of 14,3 and $0.4 \%$ for aerobic respiration, denitrification, and dissimilatory iron reduction, respectively. For the baseline case, the 

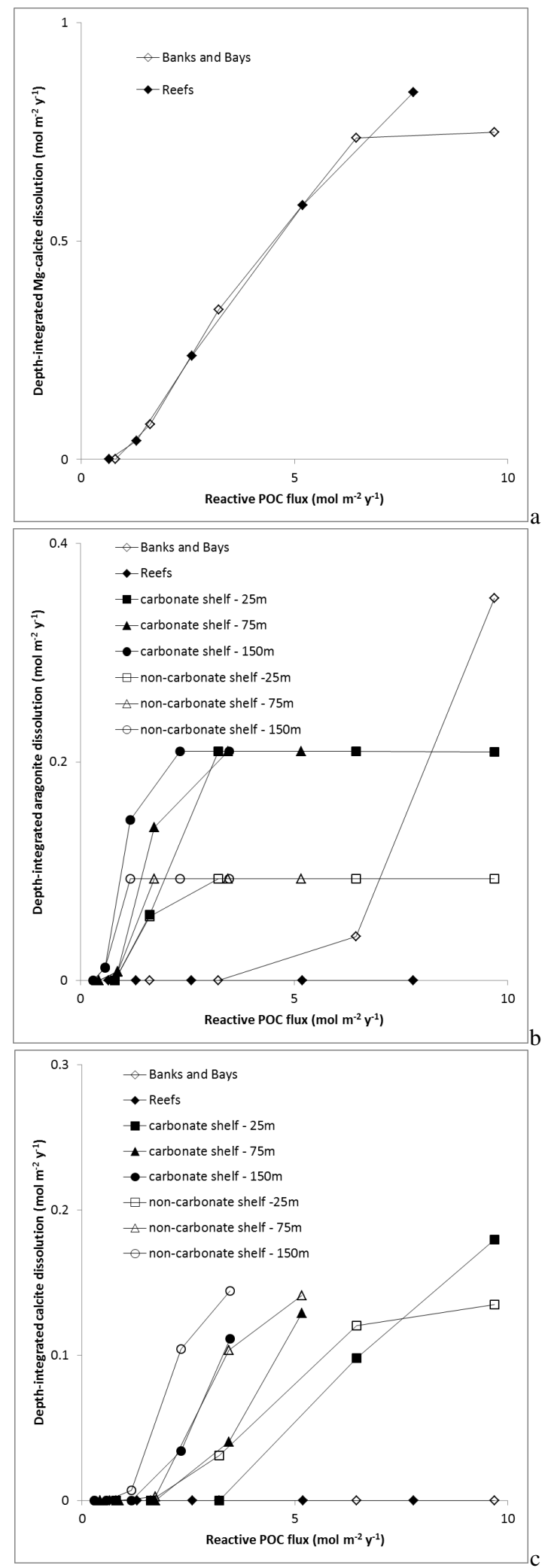

Fig. 3. Depth-integrated dissolution of (a) $15 \%$ Mg-calcite, (b) aragonite, and (c) calcite. Banks and bays $(\diamond)$, reefs $(\diamond)$, carbonate shelves: $25 \mathrm{~m}(\boldsymbol{\square}), 75 \mathrm{~m}(\boldsymbol{\Delta})$, and $150 \mathrm{~m}(\bullet)$; non-carbonate shelves: $25 \mathrm{~m}(\square), 75 \mathrm{~m}(\triangle)$, and $150 \mathrm{~m}(\circ) .15 \% \mathrm{Mg}$-calcite present only in reefs and banks and bays.

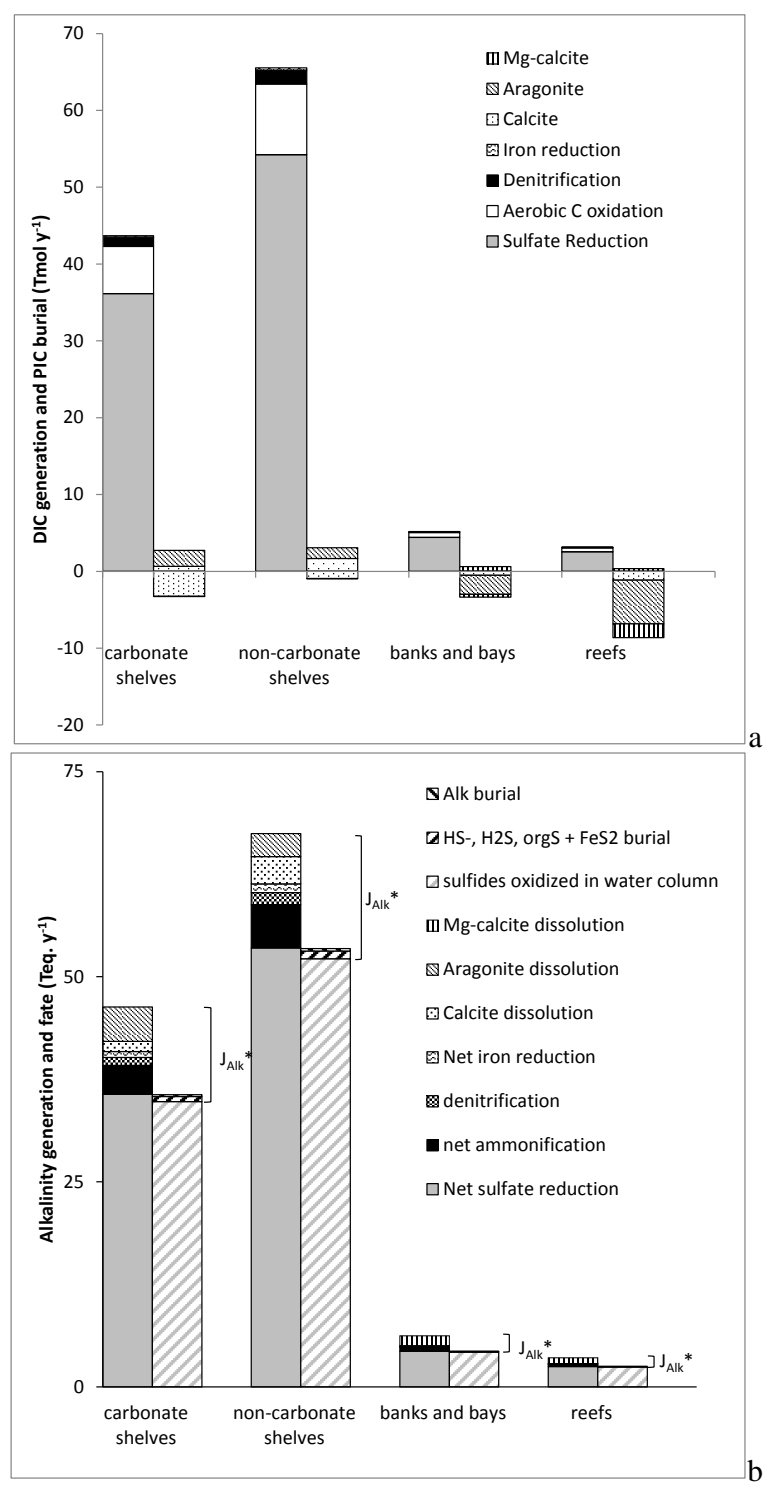

Fig. 4. Generation of DIC (a) and alkalinity (b), along with the fate of generated alkalinity and PIC by environment. Baseline coastal benthic POC deposition fluxes. (a) first column is DIC generation by C oxidation pathway; second column is PIC dissolution or burial. (b) first column is alkalinity generation by redox reactions and PIC dissolution; second column is the fate of the liberated alkalinity (burial, release to the water column as $J_{\mathrm{Alk}}{ }^{*}$, release to the water column as sulfides). Alkalinity sink due to PIC burial is also indicated.

model calculations predict that 6.8 Tmol of PIC dissolve annually, which corresponds to 28,30 , and $30 \%$ of the coastal deposition fluxes of calcite, aragonite and $\mathrm{Mg}$-calcite, respectively (Table 7). Carbonate dissolution contributes approximately $6 \%$ and $4 \%$ of the total DIC flux from carbonate and non-carbonate shelf sediments, respectively, $11 \%$ of the DIC from bank and bay sediments, and $10 \%$ of the DIC from reefs. Globally, therefore, about $5 \%$ of DIC release 
from coastal sediments $\left(7 \mathrm{Tmol} \mathrm{yr}^{-1}\right.$, Table 7) results from PIC dissolution.

In all the coastal environments, net sulfate reduction (NSR) and PIC dissolution dominate alkalinity generation (Fig. 4b). The share of in situ alkalinity generated via NSR is greatest where POC oxidation is high and PIC dissolution is relatively low: it accounts for $82 \%$ of alkalinity generated at the $25 \mathrm{~m}$ depth on non-carbonate shelves, while PIC dissolution contributes $6 \%$. Overall, on non-carbonate shelves, NSR is responsible for $79 \%$ of the alkalinity generated, and PIC dissolution contributes $9 \%$. For carbonate shelves, NSR and PIC dissolution contribute $77 \%$ and $11 \%$, respectively, to $A_{\mathrm{T}}$ generation. In both the reef and banks and bays environments, NSR contributes $70 \%$ of in situ alkalinity, while PIC dissolution contributes $20 \%$. Net ammonification is related to reactive POC deposition, and therefore its contribution to $A_{\mathrm{T}}$ is highest where POC deposition is greatest $(9 \%)$ in banks and bays and the $25 \mathrm{~m}$ depth of both carbonate and non-carbonate shelves, and lowest at the $150 \mathrm{~m}$ depth on the shelves $(4 \%)$. Denitrification and net iron reduction each contribute approximately $1-2 \%$ of in situ alkalinity generation in each of the environments. On a global scale, in situ alkalinity generation by sediment processes in the coastal zone is largely dominated by net sulfate reduction (78\%), followed by PIC dissolution (11\%), net ammonification $(7.7 \%)$, denitrification $(2.1 \%)$ and net iron reduction (1.5\%). Total alkalinity generation equals 124 Teq. $\mathrm{yr}^{-1}$ (Fig. 5b).

The effective alkalinity flux to the water column, $J_{\mathrm{Alk}}$ * (Sect. 2.5), is much smaller than the in situ alkalinity generation, because the burial of reduced sulfur is small and, thus, almost all $\mathrm{H}_{2} \mathrm{~S}+\mathrm{HS}^{-}$is reoxidized in the water column. In other words, while sulfate reduction is the major source of in situ alkalinity generation, it contributes little to $J_{\mathrm{Alk}}{ }^{*}$ (Fig. 4b). Note, however, that sulfate reduction indirectly affects $J_{\mathrm{Alk}}{ }^{*}$ through its influence on the rates of other redox processes and PIC dissolution. PIC dissolution contributes most to $J_{\mathrm{Alk}}{ }^{*}$, accounting for $65 \%$ of the effective benthic alkalinity efflux from reefs and banks and bays, $49 \%$ on carbonate shelves, and $42 \%$ on non-carbonate shelves. Net ammonification contributes $23 \%$ of $J_{\mathrm{Alk}}{ }^{*}$ in reefs, $26 \%$ in banks and bays, $32 \%$ in carbonate shelves, and $39 \%$ of $J_{\mathrm{Alk}}{ }^{*}$ on non-carbonate shelves. Globally (i.e., all coastal environments combined), PIC dissolution releases 13.5 Teq. $\mathrm{yr}^{-1}$ of $J_{\mathrm{Alk}}{ }^{*}(47 \%)$ and net ammonification $9.6 \mathrm{Teq} \cdot \mathrm{yr}^{-1}(33 \%)$. Denitrification, net iron reduction and reduced $\mathrm{S}$ burial contribute $9.0 \%, 6.6 \%$ and $5.7 \%$, respectively (Table 7).

For the baseline reactive POC deposition flux $\left(117 \mathrm{Tmol} \mathrm{yr}^{-1}\right)$, the model predicts an effective alkalinity flux $J_{\mathrm{Alk}}{ }^{*}$ from coastal sediments of 29 Teq. $\mathrm{yr}^{-1}$. This value agrees with Chen's (2002) range of $16-31$ Teq. $\mathrm{yr}^{-1}$, although the latter was estimated through a very different approach. The proposed benthic alkalinity source of 29 Teq. $\mathrm{yr}^{-1}$ is also approximately equal to the $30 \mathrm{Teq} \cdot \mathrm{yr}^{-1}$ of alkalinity supplied to the oceans by rivers (Suchet et al.,

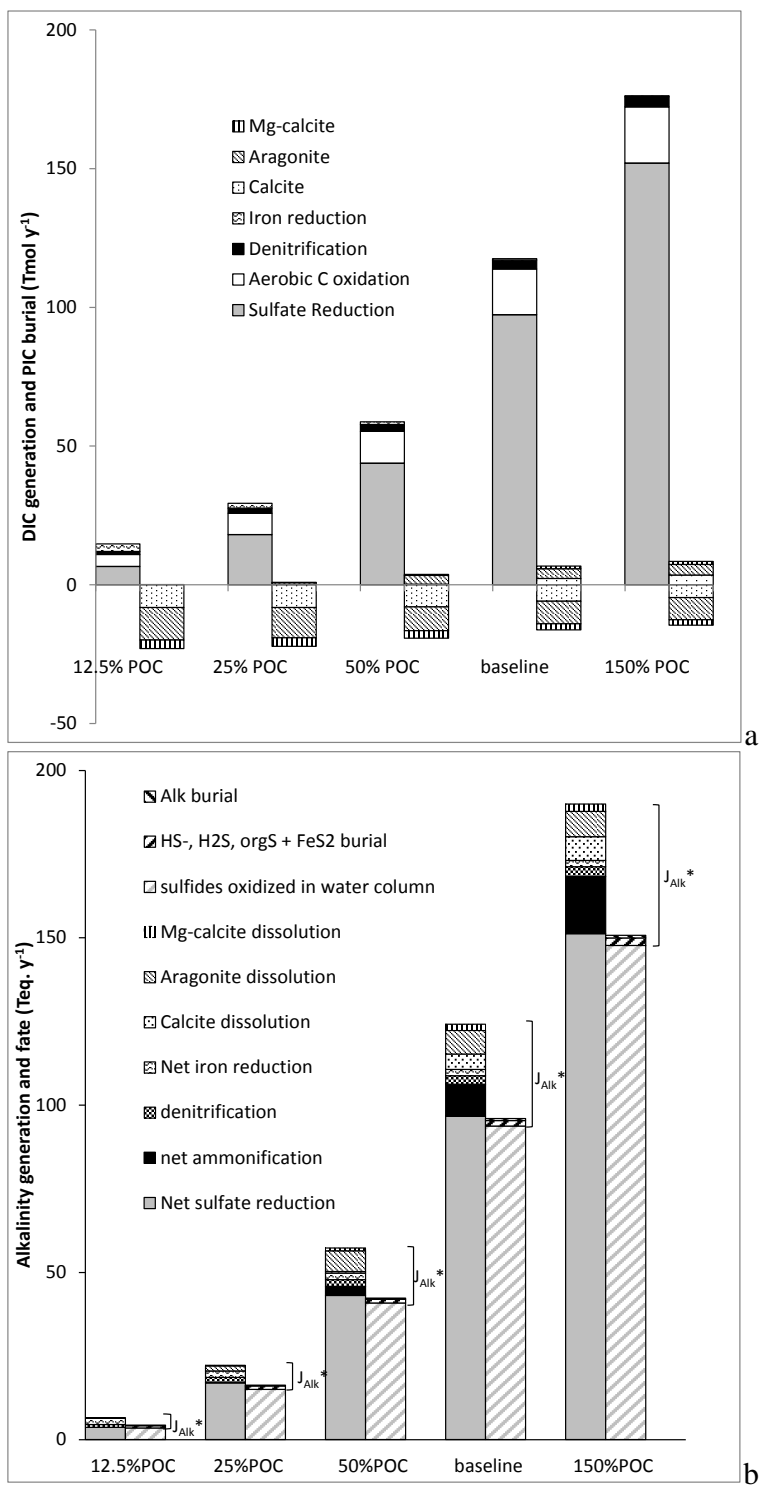

Fig. 5. Global generation of DIC (a) and alkalinity (b), along with the fate of generated alkalinity and PIC. Baseline coastal benthic POC deposition fluxes. (a) first column is DIC generation by $\mathrm{C}$ oxidation pathway; second column is PIC dissolution or burial. (b) first column is alkalinity generation by redox reactions and PIC dissolution; second column is the fate of the liberated alkalinity (burial, release to the water column as $J_{\mathrm{Alk}}{ }^{*}$, release to the water column as sulfides). Alkalinity sink due to PIC burial is also indicated.

2003). According to our calculations, PIC burial in coastal sediments represents an alkalinity sink of 32.5 Teq. $\mathrm{yr}^{-1}$. The corresponding PIC dissolution flux $\left(6.75 \mathrm{Tmol} \mathrm{yr}^{-1}\right)$ is comparable to the $6 \mathrm{Tmol} \mathrm{yr}^{-1}$ predicted by Andersson et al. (2003), although the latter dissolution flux was obtained for a much lower reactive POC deposition flux of $40 \mathrm{Tmol} \mathrm{yr}^{-1}$. With a reactive POC deposition flux of $40 \mathrm{Tmol} \mathrm{yr}^{-1}$, our model would yield a significantly lower PIC dissolution ( $\sim 2 \mathrm{Tmol} \mathrm{yr}^{-1}$, see below). 
Table 7 . Benthic $\mathrm{C}$ and alkalinity fluxes by environment, baseline case.

\begin{tabular}{|c|c|c|c|c|c|}
\hline & Reefs & Banks and Bays & Carbonate shelves & Non-carbonate shelves & Total \\
\hline Area $^{\mathrm{a}} 10^{12} \mathrm{~m}^{2}$ & 0.6 & 0.8 & 10 & 15 & 26.4 \\
\hline PIC in ${ }^{\mathrm{a}}$ Tmol yr ${ }^{-1}$ & 9 & 4 & 6 & 4 & 23 \\
\hline POC in ${ }^{\mathrm{b}} \mathrm{Tmol} \mathrm{yr}^{-1}$ & 3.1 & 5.2 & 43.7 & 65.6 & 117 \\
\hline \multicolumn{6}{|l|}{ Model outputs } \\
\hline Aerobic $\mathrm{C}$ oxidation $\mathrm{Tmol} \mathrm{yr}^{-1}$ & 0.5 & 0.6 & 6.1 & 9.2 & 16.4 \\
\hline Denitrification Tmol yr ${ }^{-1}$ & 0.1 & 0.1 & 1.2 & 1.8 & 3.2 \\
\hline Fe reduction Tmol yr ${ }^{-1}$ & 0.01 & 0.02 & 0.20 & 0.29 & 0.51 \\
\hline Sulfate reduction ${\mathrm{Tmol} \mathrm{yr}^{-1}}^{-1}$ & 2.5 & 4.4 & 36.1 & 54.1 & 97.3 \\
\hline PIC dissolution Tmol $\mathrm{yr}^{-1}$ & 0.4 & 0.6 & 2.7 & 3.1 & 6.8 \\
\hline Sediment PIC \% & 91 & 28 & 2.8 & 1.1 & - \\
\hline DIC out Tmol yr ${ }^{-1}$ & 3.5 & 5.9 & 47.0 & 69.4 & 126 \\
\hline$J_{\text {Alk_out }}$ Teq. $\mathrm{yr}^{-1}$ & 3.7 & 6.4 & 47.7 & 69.5 & 127 \\
\hline$J_{\mathrm{Alk}} *$ Teq. $\mathrm{yr}^{-1}$ & 1.1 & 1.9 & 11.1 & 14.6 & 29 \\
\hline
\end{tabular}

a Milliman and Droxler (1996).

${ }^{\mathrm{b}}$ Hatcher (1990) for reefs; the rest from depth-dependency of Soetaert et al. (2002).

\subsection{Sensitivity analyses}

\subsection{Sulfur cycling}

Sensitivity analyses with respect to internal model parameters are performed for the $75 \mathrm{~m}$ water depth carbonate shelf sediments. An increase in the sulfide oxidation rate constant, $k_{\mathrm{SulfO}_{\mathrm{x}}}$, increases the in situ sulfur recycling. As a result, 10-, $100-$, and 1000 -fold increases in $k_{\mathrm{SulfO}_{\mathrm{x}}}$ increase the contribution of sulfate reduction to POC oxidation to $82 \%, 87 \%$, and $92 \%$, respectively, at the expense of the other $\mathrm{C}$ oxidation pathways (Fig. 6a). Despite its very small relative contribution to the carbon decomposition, the accompanying declines in iron reduction cause pore water $\mathrm{pH}$ to drop to lower values (see also Jourabchi et al., 2005) and hence enhances calcite dissolution (by $82 \%$ for a 1000 -fold increase in $k_{\text {SulfO }_{\mathrm{x}}}$ ).

Faster sulfide oxidation markedly reduces net sulfate reduction (Fig. 6b), but also decreases oxygen availability for other secondary redox reactions, particularly nitrification. This in turn has a significant effect on alkalinity, as nitrification consumes alkalinity (Table 3 ). The combination of increased calcite dissolution and increased net ammonification results in a $24 \%$ increase in $J_{\mathrm{Alk}}{ }^{*}$ with a 1000 times higher than baseline value of $k_{\mathrm{SulfO}_{\mathrm{x}}}$ (Fig. 6b). Decreasing bioirrigation of sulfides (only) by $90 \%$ increases pyrite burial by $16 \%$ and calcite dissolution by $143 \%$, leading to a $7 \%$ increase in $J_{\mathrm{Alk}}{ }^{*}$. The results thus illustrate that the in situ fate of the sulfide produced by sulfate reduction can have a significant indirect effect on the effective benthic flux of alkalinity, even though the efflux of $\mathrm{H}_{2} \mathrm{~S}+\mathrm{HS}^{-}$is explicitly excluded in the definition of $J_{\mathrm{Alk}}{ }^{*}$.

\subsubsection{Iron cycling}

In our model, a doubling of the imposed reactive Fe(III) deposition flux for the $75 \mathrm{~m}$ water depth carbonate shelf sediments approximately doubles the rates of all iron-related reactions, including iron reduction and pyritization (Fig. 6b). It causes an $81 \%$ increase in pyrite burial, prevents calcite dissolution (due to higher $\mathrm{pH}$ ), and increases $J_{\mathrm{Alk}}{ }^{*}$ by $1 \%$. Pyrite burial can also be enhanced by increasing the rate constant for FeS precipitation. For a 10 -fold increase of the rate constant $k_{\mathrm{FeS}}$, the contribution of pyrite burial to $J_{\mathrm{Alk}} *$ increases by $67 \%$, while the $\mathrm{Fe}^{2+}$ efflux drops by $41 \%$. As with sulfur, changes in iron cycling within the sediments have a measurable effect on the benthic flux of alkalinity to the water column, but they hardly affect the efflux of DIC, because POC mineralization dominates DIC production in the sediments.

\subsubsection{Carbonate dissolution}

An increase of the rate constant for the PIC dissolution by $50 \%$ leads to a $21 \%$ increase in calcite dissolution (aragonite is already completely dissolved at $75 \mathrm{~m}$ on carbonate shelves), resulting in a $2 \%$ increase in $J_{\mathrm{Alk}}{ }^{*}$ (Fig. 6b). Decreasing the dissolution kinetics by $50 \%$ decreases calcite dissolution by $32 \%$ (no effect on aragonite dissolution); yet this effect on $J_{\mathrm{Alk}}{ }^{*}$ is also small ( $3 \%$ decrease).

\subsection{Response of coastal DIC and alkalinity fluxes to global environmental change}

\subsubsection{Global sensitivity to coastal productivity changes}

Estimates of reactive POC deposition flux in the coastal zone vary by more than an order of magnitude, with our baseline 


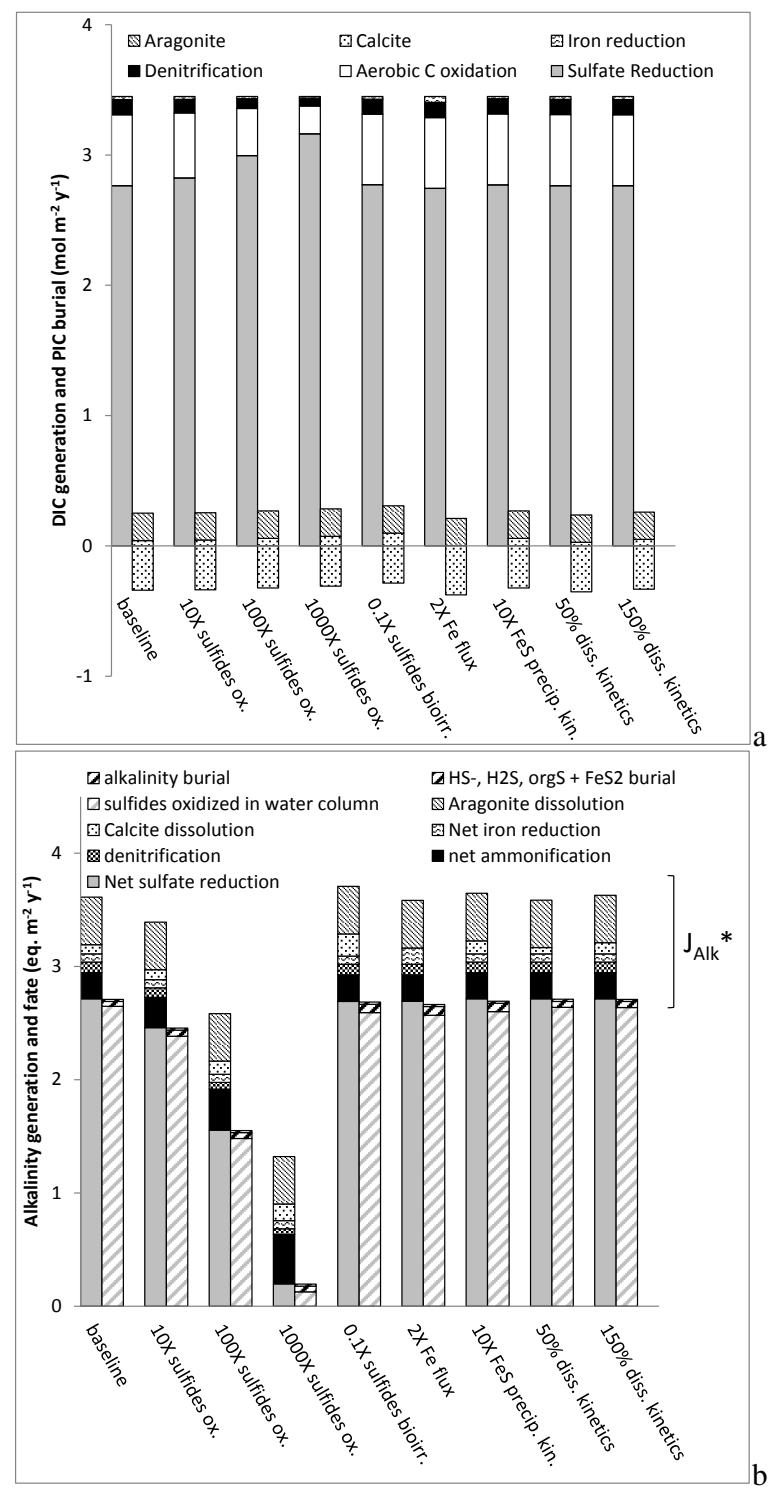

Fig. 6. Model output DIC (a) and alkalinity (b) generation sensitivity to dissolution kinetics, sulfide bioirrigation, sulfide oxidation kinetics, Fe deposition, and FeS precipitation kinetics. $75 \mathrm{~m}$ carbonate shelf environment.

estimate being at the high end of the range (Table 1). Here, we test the sensitivity of DIC and alkalinity fluxes to changes in the reactive POC deposition flux that range from $12.5 \%$ to $150 \%$ of the baseline flux (Fig. 5a). As expected, the model outcomes are highly sensitive to the reactive POC deposition flux (Fig. 5, Table 8). As the reactive POC deposition flux increases, the absolute rates of all the primary redox pathways coupled to organic $\mathrm{C}$ oxidation increase, except for iron reduction, which decreases because the reactive iron(III) deposition flux is fixed and $\mathrm{Fe}^{2+}$ reoxidation decreases, hence slowing down the internal iron redox cycle (Fig. 5a). The percentage of organic carbon oxidized via sulfate reduction grows from $45 \%$ to $86 \%$ of total POC oxidation, while the

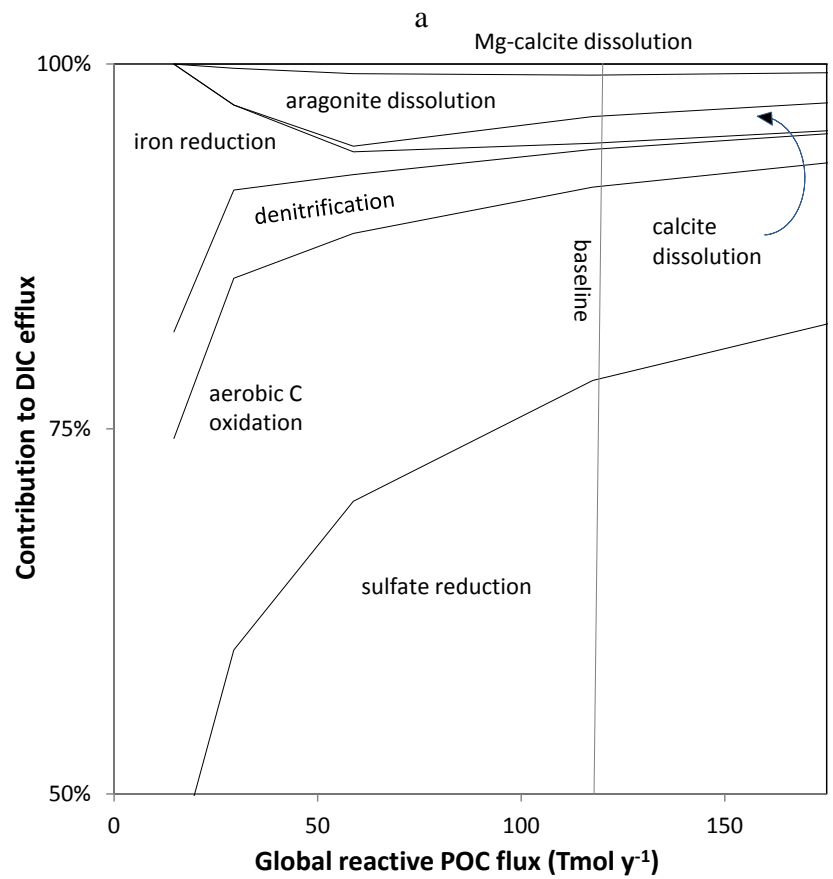

$\mathrm{b}$

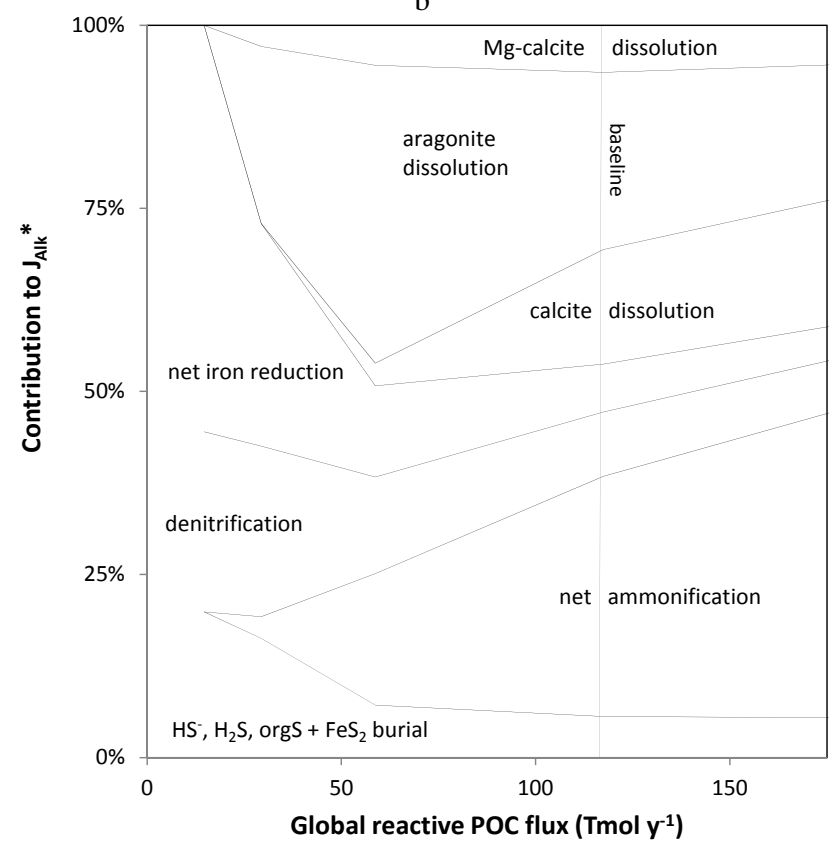

Fig. 7. Contributions of individual redox processes and PIC dissolution to DIC efflux (a) and $J_{\mathrm{Alk}}{ }^{*}$ (b) vs. POC deposition flux.

percentage of iron reduction drops sharply. At the same time, the relative contributions of aerobic respiration, denitrification, and PIC dissolution to DIC production progressively decrease (Fig. 7a).

Carbonate dissolution contributes a small amount of the benthic DIC efflux, compared to POC oxidation (Fig. 7a). The model simulations did not yield any $\mathrm{CaCO}_{3}$ dissolution when the global coastal POC flux was less than 
Table 8 . Global estimated benthic fluxes and PIC burial efficiency; POC, DIC and PIC sensitivity.

\begin{tabular}{|c|c|c|c|c|c|c|c|c|}
\hline \multirow{2}{*}{$\begin{array}{r}\text { Reactive POC flux } \\
\text { Tmol yr }^{-1}\end{array}$} & \multirow{2}{*}{$\begin{array}{r}\mathrm{SO}_{4}^{2-} \text { red. } \\
(\%)\end{array}$} & \multirow{2}{*}{$\begin{array}{r}\text { DIC out } \\
\text { Tmol yr }^{-1}\end{array}$} & \multirow{2}{*}{$\begin{array}{r}\text { Pyrite } \\
\text { Tmol yr }^{-1}\end{array}$} & \multirow{2}{*}{$\begin{array}{r}J_{\text {Alk_out }} \\
\text { T eq yr }{ }^{-1}\end{array}$} & \multirow{2}{*}{$\begin{array}{r}J_{\mathrm{Alk}}{ }^{*} \\
\mathrm{~T}_{\text {eq }} \mathrm{yr}^{-1}\end{array}$} & \multicolumn{3}{|c|}{ PIC burial efficiency (\%) } \\
\hline & & & & & & Calcite & Ara. & Mg-cal. \\
\hline 15 & 45 & 15 & 0.34 & 7 & 3 & 100 & 100 & 100 \\
\hline 29 & 62 & 31 & 0.46 & 22 & 6 & 100 & 94 & 97 \\
\hline 59 & 75 & 64 & 0.35 & 58 & 15 & 97 & 73 & 87 \\
\hline 117 & 83 & 126 & 0.32 & 127 & 29 & 72 & 70 & 70 \\
\hline 176 & 86 & 186 & 0.32 & 195 & 41 & 57 & 68 & 65 \\
\hline $117^{\mathrm{a}}$ & 83 & 127 & 0.29 & 130 & 31 & 59 & 69 & 67 \\
\hline $117^{\mathrm{b}}$ & 83 & 128 & 0.27 & 132 & 33 & 48 & 68 & 64 \\
\hline $117^{\mathrm{c}}$ & 83 & 124 & 0.31 & 123 & 24 & 40 & 65 & 51 \\
\hline
\end{tabular}

\footnotetext{
a Bottom water DIC increased by $2.5 \%$

b Bottom water DIC increased by $5 \%$.

c PIC deposition decreased by $56 \%$.

Values from baseline simulation in bold
}

$30 \mathrm{Tmol} \mathrm{yr}^{-1}$. For the lowest POC deposition flux considered in the sensitivity runs ( $12.5 \%$ of baseline flux), the pore waters remain supersaturated with respect to all the carbonate mineral phases considered in this study (Fig. 5a), with the exception of aragonite in the $150 \mathrm{~m}$ water depth shelf sediments (results not shown). Increasing POC deposition flux increases PIC dissolution (Fig. 8). Globally, $30 \%$ of the PIC deposited along the continental margins dissolves in the baseline scenario, mostly on the shelves. The remaining PIC is concentrated on reefs and banks and bays, where a small amount of dissolution is sufficient for the pore waters to reach saturation, hence allowing the carbonate minerals to be buried. With the estimated baseline deposition fluxes, $\mathrm{Mg}$-calcite is a minor contributor to DIC generation. With increasing organic matter oxidation, the aragonite dissolution flux increases up to $3.1 \mathrm{Tmol} \mathrm{yr}^{-1}$ when the reactive POC deposition flux reaches $50 \%$ of the baseline value, at which point aragonite is essentially depleted on the shelves. At higher POC deposition fluxes, calcite starts to dissolve. Overall, PIC dissolution levels out at the higher POC deposition fluxes tested, because of the depletion of carbonate phases in shelf sediments, which make up nearly $95 \%$ of the coastal area (Figs. 8 and 9b).

Despite the complex interplay of processes controlling alkalinity generation and efflux, $J_{\mathrm{Alk}} *$ increases nearly linearly with the reactive POC deposition flux (Figs. 5b and 9a). At low POC deposition fluxes, when PIC dissolution is minimal, redox processes (particularly iron reduction) and sulfide burial are the main source of $J_{\mathrm{Alk}}{ }^{*}$ (Fig. 7b). With increasing POC deposition, increased sulfate reduction and the resulting increase in sulfide re-oxidation decreases oxygen availability for other oxygenation reactions. Therefore, aerobic respiration, iron reduction, and nitrification all decrease. Aerobic C oxidation has no effect on alkalinity, and net iron reduction is fixed by the reactive iron deposition flux. In contrast, the decrease in nitrification, coupled to the increase in deposition of organic nitrogen associated with POC, leads to an in-

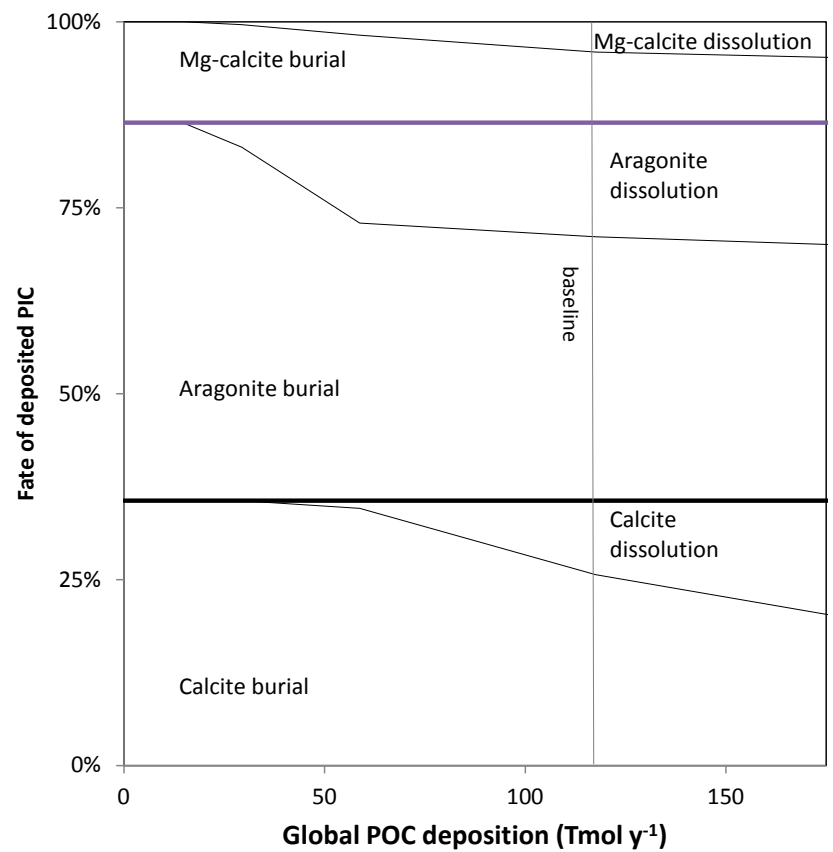

Fig. 8. Fate of PIC. Global dissolution or burial of $\mathrm{CaCO}_{3}$ phases as a function of POC deposition.

crease in net ammonification (Figs. 5b and 7b), which is the second largest contributor to $J_{\mathrm{Alk}}{ }^{*}$ (after PIC dissolution) in the baseline simulations.

Because the simulation results are most sensitive to the reactive POC deposition flux, it is possible to express the effluxes of DIC and $J_{\mathrm{Alk}}{ }^{*}$ in terms of this forcing. Over the range of POC deposition fluxes tested, the global coastal DIC efflux can thus be approximated by (Fig. 9a)

$$
J_{\text {DIC_out }}\left(\mathrm{Tmol} \mathrm{yr}^{-1}\right)=126+0.039\left(J_{\mathrm{POC}}-117\right) \text {. }
$$

For the same range of reactive POC deposition fluxes, the effective benthic alkalinity flux $\left(J_{\mathrm{Alk}}{ }^{*}\right)$ can also be 


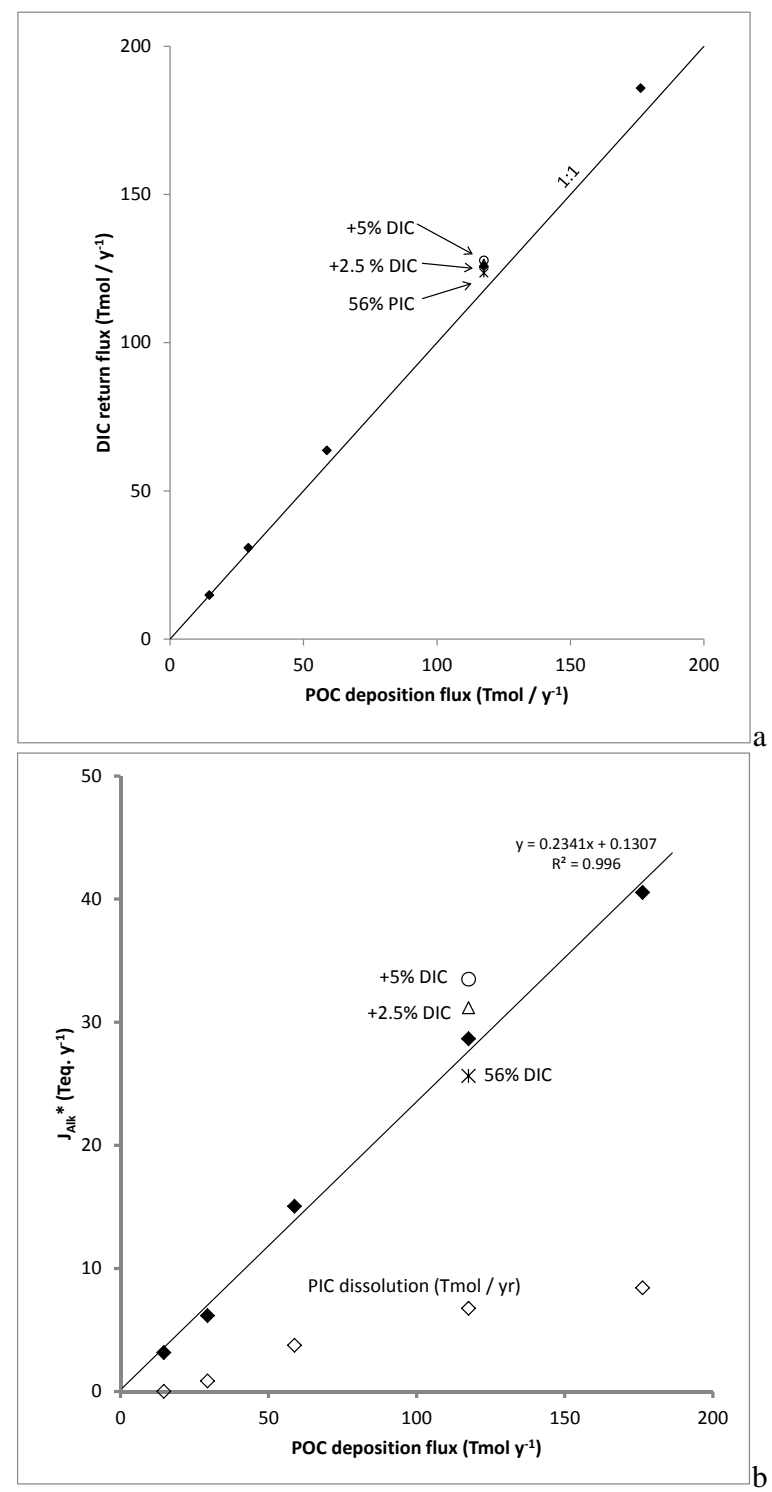

Fig. 9. Global coastal DIC return flux (a), $J_{\mathrm{Alk}}{ }^{*}$, and PIC dissolution (b), vs. POC deposition flux.

approximated by a linear function (Fig. 9b):

$J_{\mathrm{Alk}}{ }^{*}\left(\right.$ Teq. $\left.\mathrm{yr}^{-1}\right)=29+0.217\left(J_{\mathrm{POC}}-117\right)$,

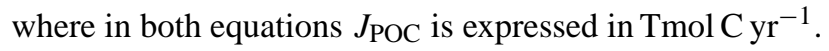

\subsubsection{Global sensitivity to ocean acidification}

An increase in bottom water DIC by $5 \%$ (which roughly corresponds to a $300 \mathrm{ppm}$ increase in atmospheric $\mathrm{CO}_{2}$ ) results in a corresponding drop in the baseline water column $\mathrm{pH}$ of 0.24 units and leads to lower carbonate concentrations and lower $\Omega_{\text {calcite }}$ throughout the sediment profile (see Fig. 1d for an example). More importantly, the zone in which calcite dissolution can occur $(\Omega<1)$ is increased in the $+5 \%$
DIC scenario compared to the baseline case, and the minimum $\Omega_{\text {calcite }}$ predicted for the ocean acidification case $(0.90)$ is lower than that for the baseline case (0.95). When extrapolated to all coastal environments, these features increase carbonate mineral dissolution from $6.8 \mathrm{Tmol} \mathrm{yr}^{-1}$ in the baseline scenario to $9 \mathrm{Tmol} \mathrm{yr}^{-1}$ (Table 8). In contrast, the reduction in bottom water $\mathrm{pH}$ has only a marginal impact on the various redox pathways considered in the model. Consequently, under the high atmospheric $\mathrm{CO}_{2}$ scenario, the model-predicted benthic DIC efflux only increases by $1.5 \%$, but $J_{\mathrm{Alk}}{ }^{*}$ increases by $17 \%$. That is, the sediments release an additional 4.4 Teq. $\mathrm{yr}^{-1}$ of alkalinity in response to the acidification of the coastal waters (Fig. 6).

Decreasing the PIC deposition flux by $56 \%$, to simulate reduced calcification triggered by ocean acidification, decreases PIC dissolution by $2.1 \mathrm{Tmol} \mathrm{yr}^{-1}$ (31\% drop relative to baseline value) globally, resulting in a $4.2 \mathrm{Teq} \cdot \mathrm{yr}^{-1}$ decrease in $J_{\mathrm{Alk}}{ }^{*}$ (i.e., a drop of $15 \%$ compared to the baseline). This is primarily accompanied by PIC depletion on the shelves. Under the baseline scenario, aragonite completely dissolves on both the carbonate and non-carbonate shelves, while only $30 \%$ of shelf-deposited calcite dissolves. With the imposed decreased PIC deposition, $100 \%$ of the calcite on the non-carbonate shelves dissolves as well. Hence, the corresponding sediments can no longer provide any additional buffering. The loss of buffering capacity of shelf sediments is not compensated by carbonate dissolution in the other benthic environments and, as a result, $J_{\mathrm{Alk}}{ }^{*}$ drops significantly. Note that the decrease in $J_{\mathrm{Alk}}{ }^{*}$ predicted for the reduced PIC deposition scenario (4.2 Teq. $\mathrm{yr}^{-1}$ ) is of the same magnitude as the increase in $J_{\mathrm{Alk}}{ }^{*}$ predicted for the high water column DIC scenario (4.4 Teq. $\mathrm{yr}^{-1}$ ). Thus, the response of coastal sediments to ocean acidification is expected to be similarly sensitive to changes in water column $\mathrm{pH}$ and calcification, within their projected ranges for the coming decades.

\section{Model limitations}

\subsection{Areal resolution}

The present model approach adopts a very coarse representation of the global coastal ocean, dividing the total coastal seafloor area of $2 \cdot 10^{7} \mathrm{~km}^{2}$ into merely four characteristic environments as described by Milliman and Droxler (1996), which are characterized by an average depth or further subdivided into three depth intervals. By averaging over such large areas, many local diagenetic features cannot be captured. The main reasons behind the approach chosen here are the scarcity and resolution of the observational data and, in particular, our current inability to obtain estimates of boundary conditions and model parameters at a finer areal resolution. In this context, the lack of higher resolution estimates of organic matter deposition fluxes and reactivity in the heterogeneous and dynamic global coastal ocean is by far the most 
important limitation towards a finer-scale regionalization of benthic C fluxes (Arndt et al., 2012).

Within a sufficiently narrow range, major model outputs such as $J_{\mathrm{Alk}}{ }^{*}$ vary roughly linearly with the driving input, POC flux (Eq. 19). To the extent that the relationship remains linear, an average value multiplied by area should give the same result as a finer-resolution model. The main complication occurs when the nature of the underlying processes changes. For example, very large local POC fluxes could eventually result in local depletion of some or all $\mathrm{CaCO}_{3}$ phases, which would limit the sediment's buffering capacity. Further POC addition could ultimately result in methanogenesis - a process that we did not include, because it is not predicted to occur in the upper sediment layers under average POC flux conditions (Regnier et al., 2011).

\subsection{Modeling approach for different environments}

An essential assumption to the model is that the sediments are accumulating carbon due to POC and PIC deposition from the overlying water column. However, in shallow environments and particularly in reefs, benthic productivity may be an important means of carbon delivery to the sediment, which is currently not accounted for. The approach presented here also may not be appropriate for modeling non-accumulating permeable sands, which may comprise up to $70 \%$ of shelf area (Jahnke et al., 2005). There is relatively little information on carbon fluxes from such sediments, but the few studies reveal a significant potential for organic oxidation and DIC release (Reimers et al., 2004; Jahnke et al., 2005; Rusch et al., 2006; Burdige et al., 2010). Further attention should thus be given to these settings in the future.

\subsection{Temporal variability}

One of the principal concerns in applying a steady-state model is its ability to capture temporal changes. Primary productivity, temperature and river inputs vary seasonally, and seawater chemistry may vary diurnally. The primary driver of all processes in the model is POC degradation, which has a rate constant of $1 \mathrm{yr}^{-1}$ for the more reactive fraction. Conditions that vary significantly more rapidly than that can presumably be represented by their average. However, similar to averaging over area, temporal averaging will be applicable only so long as the response is roughly linear and the underlying processes do not change. For example, while on average seawater remains saturated with respect to the modeled $\mathrm{CaCO}_{3}$ phases, it is possible that there are certain points in the diurnal cycle when the pore water is undersaturated. This would lead to PIC dissolution that would go unaccounted for using only averages.

The steady-state approach should be able to accurately reflect changes to boundary conditions that occur significantly slower than the slowest applicable timescale. While reactions are driven by organic matter degradation, solids advection through the top $20 \mathrm{~cm}$ of sediment (where the vast majority of reactions occur) will take ca. $50 \mathrm{yr}$. Therefore, the steadystate model should be adequate to capture the effects of seawater DIC changes induced by global environmental change, as they are expected to rise by only $5 \%$ over the next century. Accurately modeling the effect on sediment solids of an approximately $50 \%$ increase in POC deposition by the year 2100 (Andersson et al., 2005) may require a transient implementation of the model.

\subsection{POC fluxes}

Previously published estimates of the global POC deposition flux vary by more than an order of magnitude (Table 1). The average value of these estimates is ca. $101 \mathrm{Tmol} \mathrm{yr}^{-1}$. Therefore, our baseline simulation with a reactive POC deposition flux of $117 \mathrm{Tmol} \mathrm{yr}^{-1}$ and a total flux of $136 \mathrm{Tmol} \mathrm{yr}^{-1}$ should be viewed as an upper-bound estimate for DIC and $J_{\text {Alk }}{ }^{*}$ fluxes. The results of the sensitivity study indicate that, for the bulk range of $60-120 \mathrm{Tmol} \mathrm{yr}^{-1}$, the predicted global coastal ocean flux of $J_{\mathrm{Alk}}{ }^{*}$ is most likely constrained within a factor of 2 (Fig. 5b). Over this POC flux range, degradation-driven dissolution of shallow water carbonates generates $\sim 4-7 \mathrm{Tmol} \mathrm{yr}^{-1}$ of $J_{\mathrm{Alk}}{ }^{*}$, while the total irreversible buffering source of alkalinity from shallow marine sediments (PIC dissolution, denitrification and sulfur burial) is on the order of $11-19 \mathrm{Tmol} \mathrm{yr}^{-1}$. Taking the contribution of net ammonification and net iron reduction, $J_{\mathrm{Alk}} *$ fluxes increase to 16-29 $\mathrm{Tmol} \mathrm{yr}^{-1}$ (Fig. 5b). In contrast, the uncertainty in key internal model parameter values has little influence on the uncertainty in estimated $J_{\mathrm{Alk}}{ }^{*}$ fluxes for a given POC flux (Fig. 6b).

\subsection{Organic matter reactivity and quality}

The overall reactivity of POC is probably one of the weakest constrained parameters. Coastal sediments receive highly variable organic matter loads from very different sources (fossil, terrestrial, in-situ produced or laterally transported, pre-aged marine organic matter) and are subject to erosion/deposition cycles, as well as a strong temporal variability and a marked seasonality. The dynamic and heterogeneous nature of these organic matter inputs is reflected in extremely variable organic radio-carbon ages $\left({ }^{14} \mathrm{C}\right.$ contents of total organic carbon as fraction of modern $F=1-0.1$; Griffith et al., 2010) and model-derived organic matter degradation rate constants $\left(k=10^{2}-10^{-2} \mathrm{yr}^{-1}\right.$; Arndt et al., 2012). Understanding this high degree of variability in coastal organic matter reactivity and developing a general framework that allows constraining organic matter reactivity in datapoor areas is currently not achievable with the existing set of model-derived values. In addition, previously published global relationships between organic matter reactivity and easily observable quantities, such as sedimentation rate or 
organic matter deposition flux, may not be accurate predictors for coastal sediments. This is because they are based on a limited number of studies, predominantly from the open ocean. At the global scale, $2 \mathrm{G}$ models assign $51-92 \%$ of the deposited organic matter to the most reactive fraction while 8-49\% are assigned to the least reactive fraction (Hammond et al., 1996; Rabouille et al., 1998; Luff and Moll, 2004; Arndt et al., 2012). However, organic matter depositing in coastal sediments represents a complex and dynamic mixture of organic matter of variable origin and age (e.g., Mollenhauer et al., 2005). Our partitioning of $67 \%$ "fast" POC $\left(k=1 \mathrm{yr}^{-1}\right), 17 \%$ "slow" POC $\left(k=0.1 \mathrm{yr}^{-1}\right)$ and $16 \%$ nondegradable POC can be considered as a compromise reflecting this complex mixture.

In this model, all degradable organic matter is assumed to have Redfield stoichiometry. Organic matter deposition to coastal sediments is expected to contain a relatively high input of terrestrial organic matter, which is relatively poorly characterized with respect to composition or reactivity compared with algae. It presumably has lower reactivity and higher $\mathrm{C}$ content (higher $\mathrm{C}: \mathrm{N}$ ) than algal biomass. Variations in $\mathrm{C}: \mathrm{N}$ ratio of degrading organic matter affect the reaction stoichiometries. For instance, higher $\mathrm{C}: \mathrm{N}$ ratios would release less ammonium and consume fewer protons (see R1). As discussed in Sect. 3.1.3, nitrification consumes more alkalinity than is generated during protonation of ammonia. However, in all modeled cases, "net ammonification" (the alkalinity effect of ammonification minus that of nitrification) is positive. We therefore expect that a decrease in the $\mathrm{N}$ content of the degrading organic matter will decrease net alkalinity generation by combined ammonification and nitrification. The effect on denitrification will be muted, because redox process rates are to a large extent determined by the POC hydrolysis rate and the rates of competing redox processes. Therefore, the overall effect of decreased $\mathrm{C}: \mathrm{N}$ during organic matter degradation should be a small decrease in alkalinity generation within the sediment.

Terrestrial POC is also expected to be more refractory than that produced in the water column (Andersson et al., 2005). We limit our study to more labile phases, which is likely to exclude a large fraction (though not all) of the terrestrial organic matter. Implementing a model that distinguishes between terrestrial and pelagic POC would require detailed knowledge of regional sources of POC, which is beyond the scope of this modeling effort.

\subsection{Other boundary conditions}

After POC flux, the other boundary conditions such as bottom water oxygen, nitrate, DIC or temperature exert a second-order influence on $J_{\mathrm{Alk}}{ }^{*}$ estimates. In particular, temperature effects are small in our model, because the only temperature-dependent aspects of the model are diffusion coefficients, equilibrium constants, and the solubility of the carbonate phases, while organic matter decomposition, which is the main driver of PIC dissolution and $J_{\mathrm{Alk}}{ }^{*}$ generation, is modeled as independent of temperature. Explicitly accounting for the effect of temperature on primary redox reactions is not straightforward. Observations show, however, that the dominant microbial populations in each environment are optimally adapted to the prevailing environmental conditions and mineralization rates in permanently cold Arctic sediments are similar to those of temperate nearshore environments (Arnosti et al., 1998; Kostka et al., 1999; Jørgensen, 2006; Arndt et al., 2012).

\subsection{Secondary redox processes}

The modeled secondary redox processes are limited to the reactions of major reduced species $\left(\mathrm{NH}_{4}^{+}, \mathrm{Fe}^{2+}, \mathrm{HS}^{-}\right.$, and $\mathrm{FeS}$ ) with oxygen. There is a great deal of uncertainty in published kinetic parameters for these reactions. Our sensitivity analysis on sulfide oxidation kinetics suggests that even large (several orders of magnitude) changes in the kinetics of this process will result in changes in benthic return fluxes of DIC and $A_{\mathrm{T}}$ that are relatively small compared with those related to uncertainty associated with POC deposition fluxes. This effect is further complicated by bioirrigation of reduced species out of the sediment, which is also rather uncertain.

In order to minimize model complexity and uncertainty, we did not model several other possible reactions, including oxidation of sulfides by $\mathrm{Fe}^{3+}, \mathrm{NO}_{3}^{-}$, or $\mathrm{Mn}^{4+}$. These reactions also consume alkalinity and would be expected to increase $\mathrm{CaCO}_{3}$ dissolution and should be addressed in future research.

Despite these limitations, our modeling study provides a first-order global estimate of the coupled carbon dynamics in coastal sediments and of the associated benthic DIC and alkalinity fluxes. It also reveals knowledge and data gaps in our understanding of DIC and alkalinity fluxes, unravels the sensitivity of coastal carbon cycling to ongoing global environmental change and highlights the need for comparative, spatially resolved approaches in understanding and quantifying global coastal ocean biogeochemical dynamics.

\section{Synthesis}

A one-dimensional reactive transport model (RTM) of early diagenesis is used to describe primary and secondary redox reactions and their impact on the dissolution of carbonate mineral phases (calcite, aragonite, and $15 \% \mathrm{Mg}$-calcite) in shallow marine sediments. The model predictions are extrapolated to estimate benthic fluxes of DIC and alkalinity for the global coastal ocean, based on the benthic typology proposed by Milliman and Droxler (1996). However, because our baseline scenario falls in the higher range of global coastal POC deposition fluxes reported in the literature, the absolute flux values should be viewed as upperbound estimates. The results highlight the dominant role of 
anaerobic respiration, mainly sulfate reduction, in the decomposition of sediment organic matter; hence, as a source of benthic DIC in the coastal ocean (77\% of the baseline DIC efflux of $126 \mathrm{Tmol} \mathrm{yr}^{-1}$ ). The oxidation of organic carbon is estimated to cause the dissolution of approximately $7 \mathrm{Tmol} \mathrm{yr}^{-1}$ of shallow-water marine carbonate minerals (circa $0.1 \mathrm{Pg} \mathrm{Cyr}^{-1}$ ). As expected, the predicted carbonate dissolution flux is very sensitive to the supply of reactive organic matter to the sediments. For an increase of the reactive POC deposition flux by a factor 1.5 , carbonate dissolution increases by about $20 \%$.

For the baseline reactive POC deposition flux of $117 \mathrm{Tmol} \mathrm{yr}^{-1}$ (total POC deposition flux of $136 \mathrm{Tmol} \mathrm{yr}^{-1}$ ), the model-derived total alkalinity efflux from the sediments is 120 Teq. $\mathrm{yr}^{-1}$. A large fraction of this efflux is under the form of reduced solutes that are highly unstable in oxygenated waters and, therefore, are unlikely to serve as buffer against rising atmospheric $\mathrm{CO}_{2}$ and ocean acidification. By assuming that free sulfide reaching the sediment-water interface is instantaneously and quantitatively oxidized, the effective benthic alkalinity flux to the water column $\left(J_{\mathrm{Alk}}{ }^{*}\right)$ is 29 Teq. $\mathrm{yr}^{-1}$. The two main contributions to $J_{\mathrm{Alk}}{ }^{*}$ are carbonate dissolution (46\%) and net ammonification (33\%), with smaller contributions from denitrification $(9 \%)$, net iron reduction $(7 \%)$, and reduced sulfur burial $(6 \%)$. Subtracting net ammonification from $J_{\mathrm{Alk}}{ }^{*}$ results in a minimum estimate of the effective benthic alkalinity supply to the global coastal ocean on the order of 19 Teq. $\mathrm{yr}^{-1}$.

While our estimate of the effective benthic alkalinity flux $J_{\mathrm{Alk}}{ }^{*}$ of $29 \mathrm{Teq} . \mathrm{yr}^{-1}$ compares well with the range of 16 to 31 Teq. $\mathrm{yr}^{-1}$ proposed by Chen (2002) for the coastal ocean, our analysis of the underlying sedimentary processes is quite different. Chen and Wang (1999) attribute over $80 \%$ of the benthic alkalinity flux to iron and sulfate reduction, with no contribution from carbonate mineral dissolution. Our analysis is thus more in line with that of Berelson et al. (2007), who acknowledge the production of alkalinity by carbonate dissolution, along with sulfate reduction and the reoxidation of sulfide by iron oxides. These authors report an average alkalinity efflux from California margin sediments of about $2.5 \mathrm{meq} \mathrm{m}^{-2} \mathrm{~d}^{-1}$, which is close to the average $J_{\mathrm{Alk}}{ }^{*}$ flux we calculate for carbonate and non-carbonate shelf sediments $\left(\sim 2.8 \mathrm{meq} \mathrm{m}^{-2} \mathrm{~d}^{-1}\right)$. In contrast, Hu and Cai (2011) report a significantly lower flux of alkalinity (4-5 Teq. $\mathrm{yr}^{-1}$ ) generated by ocean margin sediments. Their estimate only takes into account net benthic denitrification and pyrite burial, because the authors implicitly treat the coastal water column plus the underlying sediments as a single system and, hence, alkalinity-producing benthic processes that are (or could be) counteracted by alkalinity-consuming processes in the water column are not considered. The authors also do not include carbonate precipitation and dissolution, because their focus is on anaerobic processes. Using this whole-coastal ocean approach, yet focusing only on anaerobic processes, leads $\mathrm{Hu}$ and Cai to omit the two major sources of $J_{\mathrm{Alk}}{ }^{*}$ included in our model: carbonate dissolution and ammonification. Once the differences in system delineation (whole ocean versus sediments, anaerobic processes only vs. coupled redox and dissolution) are recognized, the alkalinity fluxes assigned by $\mathrm{Hu}$ and Cai to denitrification (1.5 $\mathrm{Teq}^{-1} \mathrm{r}^{-1}$ ) and pyrite burial (2.4-3.3 Teq. $\mathrm{yr}^{-1}$ ) are nevertheless comparable to our baseline estimates of $2.6 \mathrm{Teq} . \mathrm{yr}^{-1}$ for coastal zone denitrification, and 1.6 Teq. $\mathrm{yr}^{-1}$ (Fig. 5b) for reduced sulfur burial.

Despite the diversity of approaches, relatively coherent estimates of the contribution of sediment biogeochemical processes to benthic DIC and alkalinity fluxes in nearshore and continental shelf environments are emerging. With the early diagenetic modeling approach used here, it is further possible to analyze the sensitivity of the benthic fluxes to external forcings and model parameters. This strengthens our ability to predict the response of benthic DIC and alkalinity fluxes from coastal sediments to anthropogenic perturbations, in particular coastal eutrophication and ocean acidification.

\section{Supplementary material related to this article is

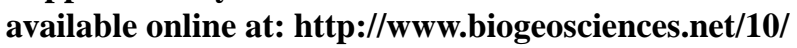 371/2013/bg-10-371-2013-supplement.pdf.}

Acknowledgements. This work is a contribution to the "European Project on Ocean Acidification" (EPOCA) which received funding from the European Community's Seventh Framework Programme (FP7/2007-2013) under grant agreement no. 211384. It has been supported by the government of the Brussels-Capital Region (Brains Back to Brussels award to PR), by the Netherlands Organization for Scientific Research (NWO) (VIDI award to PR) and by the National Environment Research Council (NERC Fellowship to SA). The research leading to these results also received funding from the European Union's Seventh Framework Program (FP7/2007-2013) under grant agreement no 283080, project GEOCARBON.

Edited by: F. Meysman

\section{References}

Aguilera, D. R., Jourabchi, P., Spiteri, C., and Regnier, P.: A knowledge-based reactive transport approach for the simulation of biogeochemical dynamics in Earth systems, Geochem. Geophy. Geosy., 6, Q07012, doi:10.1029/2004GC000899, 2005.

Andersson, A. J., Mackenzie, F. T., and Ver, L. M.: Solution of shallow-water carbonates: An insignificant buffer against rising atmospheric $\mathrm{CO}_{2}$, Geology, 31, 513-516, 2003.

Andersson, A. J., Mackenzie, F. T., and Lerman, A.: Coastal ocean and carbonate systems in the high $\mathrm{CO}_{2}$ world of the Anthropocene, Am. J. Sci., 305, 875-918, 2005.

Andersson, A. J., Mackenzie, F. T., and Gattuso, J. P.: Effects of ocean acidification on benthic processes, organisms, and ecosys- 
tems, in: Ocean acidification, edited by: Gattuso J.-P. and Hansson L., Ocean acidification, 122-153, Oxford, Oxford University Press, 2011.

Anggara Kasih, G., Chiba, S., Yamagata, Y., Shimizu, Y., and Haraguchi, K.: Modeling early diagenesis of sediment in Ago Bay, Japan: A comparison of steady state and dynamic calculations, Ecol. Model., 215, 40-54, 2008.

Archer, D. E., Morford, J. L., and Emerson, S. R.: A model of suboxic sedimentary diagenesis suitable for automatic tuning and gridded global domains, Global Biogeochem. Cy., 16, 17-1-1721, DOI: 10.1029/2000GB001288, 2002.

Archer, D., Eby, M., Brovkin, V., Ridgwell, A., Cao, L., Mikolajewicz, U., Caldeira, K., Matsumoto, K., Munhoven, G., and Montenegro, A.: Atmospheric lifetime of fossil fuel carbon dioxide, Annu. Revi. Earth Pl. Sc., 37, 117-134, 2009.

Arndt, S., Regnier, P., Goddéris, Y., and Donnadieu, Y.: GEOCLIM reloaded ( $\mathrm{v}$ 1.0): a new coupled earth system model for past climate change, Geosci. Model Dev., 4, 451-481, doi:10.5194/gmd-4-451-2011, 2011.

Arndt, S., Jorgensen, B. B., LaRowe, D. E., Middelburg, J. J., Pancost, R., and Regnier, P.: Quantifying Organic matter degradation in marine sediments: A synthesis and review, Earth-Sci. Rev., in review, 2012.

Arnosti, C., Jørgensen, B. B., Sageman, J., and Thamdrup, B.: Temperature dependence of microbial degradation of organic matter in marine sediments: polysaccharide hydrolysis, oxygen consumption, and sulfate reduction, Mar. Ecol. Prog.-Ser., 165, 5970, 1998.

Berelson, W. M., Balch, W. M., Najjar, R., Feely, R. A., Sabine, C., and Lee, K.: Relating estimates of $\mathrm{CaCO}_{3}$ production, export, and dissolution in the water column to measurements of $\mathrm{CaCO}_{3}$ rain into sediment traps and dissolution on the sea floor: A revised global carbonate budget, Global Biogeochem. Cy., 21, GB1024, doi:10.1029/2006GB002803, 2007.

Berg, P., Rysgaard, S., and Thamdrup, B.: Dynamic Modeling of Early Diagenesis and Nutrient Cycling. A Case Study in an Artic Marine Sediment, Am. J. Sci., 303, 905-955, 2003.

Berner, R. A.: Burial of organic carbon and pyrite sulfur in the modern ocean: its geochemical and environmental significance, Am. J. Sci, 282, 451-473, 1982.

Blair, N. E. and Aller, R. C.: Anaerobic methane oxidation on the Amazon shelf, Geochim. Cosmochim. Ac., 59, 3707-3715, 1995.

Boudreau, B. P.: Is burial velocity a master parameter for bioturbation?, Geochim. Cosmochim. Ac., 58, 1243-1249, 1994.

Boudreau, B. P.: Diagenetic models and their implementation: modelling transport and reactions in aquatic sediments, SpringerVerlag, Berlin, 1996.

Boudreau, B. P. and Canfield, D. E.: A comparison of closedand open-system models for porewater $\mathrm{pH}$ and calcite-saturation state, Geochim. Cosmochim. Ac., 57, 317-334, 1993.

Bosence, D. W. J., Royston, J. R., and Quine, M. L.: Sedimentology and budget of a recent carbonate mount, Florida Keys, Sedimentology, 3, 317-343, 1985.

Burdige, D. J.: The kinetics of organic matter mineralization in anoxic marine sediments, J. Mar. Res., 49, 727-761, 1991.

Burdige, D. J., Hu, X., and Zimmerman, R. C.: The widespread occurrence of coupled carbonate dissolution/reprecipitation in surface sediments on the Bahamas Bank, Am. J. Sci., 310, 492-521,
2010.

Caldeira, K. and Wickett, M. E.: Anthropogenic carbon and ocean pH, Nature, 425, 365-365, 2003.

Canfield, D. E.: Sulfate reduction and oxic respiration in marine sediments: implications for organic carbon preservation in euxinic environments, Deep-Sea Res. Pt. A, 36, 121-138, 1989.

Canfield, D. E.: The sulfur cycle, Adv. Mar. Biol., 48, 313-381, 2005.

Carignan, R. and Tessier, A.: The co-diagenesis of sulfur and iron in acid lake sediments of southwestern Quebec, Geochim. Cosmochim. Ac., 52, 1179-1188, 1988.

Centler, F., Shao, H., De Biase, C., Park, C.H., Regnier, P., Kolditz, O., and Thullner, M.: GeoSysBRNS - A flexible multidimensional reactive transport model for simulating biogeochemical subsurface processes, Comput. Geosci., 36, 397-405, 2010.

Chen, C. T. A.: Shelf-vs. dissolution-generated alkalinity above the chemical lysocline, Deep-Sea Res. Pt. II, 49, 5365-5375, 2002.

Chen, C. T. A. and Wang, S. L.: Carbon, alkalinity and nutrient budgets on the East China Sea continental shelf, J. Geophys. Res., 104, 20675-20686, 1999.

Chen, C. T. A., Liu, K. K., and MacDonald, R.: Continental margin exchanges, Ocean Biogeochemistry, 53-97, Springer-Verlag, Berlin, 2003.

Cloern, J. E.: Our evolving conceptual model of the coastal eutrophication problem, Mar. Ecol. Prog.-Ser., 210, 223-253, 2001.

Dale, A. W., Regnier, P., Knab, N. J., Jorgensen, B. B., and Van Cappellen, P.: Anaerobic oxidation of methane (AOM) in marine sediments from the Skagerrak (Denmark): II. Reaction-transport modeling, Geochim. Cosmochim. Ac., 72, 2880-2894, 2008.

Dale, A. W, Brüchert, V., Alperin, M., and Regnier, P.: An integrated sulfur isotope model for Namibian shelf sediments, Geochim. Cosmochim. Ac., 73, 1924-1944, 2009.

Dulaiova, H., Ardelan, M. V., Henderson, P. B., and Charette, M. A.: Shelf-derived iron inputs drive biological productivity in the southern Drake Passage, Global Biogeochem. Cy., 23, GB4014, doi:10.1029/2008GB003406, 2009.

Dunne, J. P., Sarmiento, J. L., and Gnanadesikan, A.: A synthesis of global particle export from the surface ocean and cycling through the ocean interior and on the seafloor, Global Biogeochem. Cy., 21, GB4006, doi:10.1029/2006GB002907, 2007.

Epping, E., van der Zee, C., Soetaert, K., and Helder, W.: On the oxidation and burial of organic carbon in sediments of the Iberian margin and Nazaré Canyon (NE Atlantic), Prog. Oceanogr., 52, 399-431, 2002.

Feely, R. A., Sabine, C. L., Lee, K., Berelson, W., Kleypas, J., Fabry, V. J., and Millero, F. J.: , Impact of anthropogenic $\mathrm{CO}_{2}$ on the $\mathrm{CaCO}_{3}$ system in the oceans, Science, 305, 362-366, 2004.

Gangst $\varnothing$, R., Gehlen, M., Schneider, B., Bopp, L., Aumont, O., and Joos, F.: Modeling the marine aragonite cycle: changes under rising carbon dioxide and its role in shallow water $\mathrm{CaCO}_{3}$ dissolution, Biogeosciences, 5, 1057-1072, doi:10.5194/bg-5-10572008, 2008.

Griffith, D. R., Martin, W. R., and Eglinton, T. I.: The radiocarbon age of organic carbon in marine surface sediments, Geochim. Cosmochim. Ac., 74, 6788-6800, 2010.

Hammond, D. E., McManus, J., Berelson, W. M., Kilgore, T. E., and Pope, R. H.: Early diagenesis of organic material in equatorial Pacific sediments: stpichiometry and kinetics, Deep-Sea Res. Pt. II, 43, 1365-1412, 1996. 
Hatcher, B. G.: Coral reef primary productivity. A hierarchy of pattern and process, Trends Ecol. Evol., 5, 149-155, 1990.

Henrichs, S. M. and Doyle, A. P.: Decomposition of 14 C-labeled organic substances in marine sediments, Limnol. Oceanogr., 31, 765-778, 1986.

$\mathrm{Hu}, \mathrm{X}$. and Cai, W. J.: An assessment of ocean margin anaerobic processes on oceanic alkalinity budget, Global Biogeochem. Cy., GB3003, doi:10.1029/2010GB003859, 2011.

Jahnke, R. A.: Global Synthesis 1 in Carbon and Nutrient Fluxes in Continental Margins, edited by: Liu, K.-K., Atkinson, L., Quinones, R., and Talaue-Mcmanus, L., Springer, Berlin, 597$615,2010$.

Jahnke, R. A., Craven, D. B., and Gaillard, J. F.: The influence of organic matter diagenesis on $\mathrm{CaCO} 3$ dissolution at the deep-sea floor, Geochim. Cosmochim. Ac., 58, 2799-2809, 1994.

Jahnke, R., Richards, M., Nelson, J., Robertson, C., Rao, A., and Jahnke, D.: Organic matter remineralization and porewater exchange rates in permeable South Atlantic Bight continental shelf sediments, Cont. Shelf Res., 25, 1433-1452, 2005.

Joos, F., Plattner, G. K., Stocker, T. F., Marchal, O., and Schmittner, A.: Global warming and marine carbon cycle feedbacks on future atmospheric $\mathrm{CO}_{2}$, Science, 284, 464-467, 1999.

Jørgensen, B. B. and Fenchel, T.: The sulfur cycle of a marine sediment model system, Mar. Biol., 24, 189-201, 1974.

Jørgensen, B. B.: A comparison of methods for the quantification of bacterial sulfate reduction in coastal marine sediments, Geomicrobiol. J., 1, 29-47, 1978.

Jørgensen, B. B.: Mineralization of organic-matter in the sea bedthe role of sulfate reduction, Nature, 296, 643-645, 1982.

Jørgensen, B. B.: Bacteria and marine biogeochemistry, in: Marine Geochemistry, edited by: Schulz, H. D. and Zabel, M., Springer, Berlin, 169-206, 2006.

Jourabchi, P., van Cappellen, P., and Regnier, P.: Quantitative interpretation of $\mathrm{pH}$ distributions in aquatic sediments: A reactiontransport modeling approach, Am. J. Sci., 305, 919-956, 2005.

Kaplan, I. R., Emery, K. O., and Rittenberg, S. C.: The distribution and isotopic abundance of sulphur in recent marine sediments off southern California, Geochim. Cosmochim. Ac., 27, 297-312, 1963.

Katsev, S., Chaillou, G., and Sundby, B.: Effects of progressive oxygen depletion on sediment diagenesis and fluxes: A model for the lower St. Lawrence River Estuary, Limnol. Oceanogr., 52, 25552568, 2007.

Kleypas, J. A., Buddemeier, R. W., Eakin, C. M., Gattuso, J. P., Guinotte, J., Hoegh-Guldberg, O., Iglesias-Prieto, R., Jokiel, P.L., Langdon, C., and Skirving, W.: Comment on "Coral reef calcification and climate change: the effect of ocean warming", Geophys. Res. Lett., 32, L08601, doi:10.1029/2004GL022329, 2005.

Koeve, W.: Upper ocean carbon fluxes in the Atlantic Ocean: The importance of the POC : PIC ratio, Global Biogeochem. Cy., 16, $1-17,2002$.

Kostka, J. E., Thamdrup, B., Glud, R. N., and Canfield, D. E.: Rates and pathways of carbon oxidation in permanently cold Arctic sediments, Mar. Ecol.-Prog. Ser., 180, 7-21, 1999.

Land, L. S.: Diagenesis of skeletal carbonates, J. Sediment. Petrol., 37, 914-930, 1967.

Luff, R. and Moll, A.: Seasonal dynamics of the North Sea sediments using a three-dimensional coupled sediment-water model system, Cont. Shelf Res., 24, 1099-1127, 2004.

Luff, R. and Wallmann, K.: Fluid flow, methane fluxes, carbonate precipitation and biogeochemical turnover in gas hydrate-bearing sediments at Hydrate Ridge, Cascadia Margin: numerical modeling and mass balances, Geochim. Cosmochim. Ac., 67, 34033421, 2003.

Mackenzie, F. T., Lerman, A., and Ver, L. M..: Role of the continental margin in the global carbon balance during the past three centuries, Geology, 26, 5, 423-426, 1998.

Mackenzie, F. T., Andersson, A., Lerman, A., Ver, L. M.: Boundary exchanges in the global coastal margin: Implications for the organic and inorganic carbon cycles, in: The Sea, 13, 193-225, edited by: Robinson, A. R. and Brink, K. H., Harvard University Press, Cambridge, 2005.

Martens, C., Alperin, M., and Albert, D.: Deposition and fate of modern organic carbon in shelf/upper slope sediments near Cape Hatteras, North Carolina, Final report: Department of Marine Sciences, University of North Carolina at Chapel Hill, Chapel Hill, NC, USA, 1998.

Meile, C., Berg, P., Van Cappellen, P., and Tuncay, K.: Solutespecific pore water irrigation: Implications for chemical cycling in early diagenesis, J. Mar. Res., 63, 601-621, 2005.

Middelburg, J. J., Soetaert, K., and Herman, P. M. J.: , Empirical relationships for use in global diagenetic models, Deep-Sea Res. Pt. I, 44, 327-344, 1997.

Millero, F. J.: Thermodynamics of the carbon dioxide system in the oceans, Geochim. Cosmochim. Ac., 59, 661-677, 1995.

Milliman, J. D.: Production and Accumulation of Calcium Carbonate in the Ocean: Budget of a Nonsteady State, Global Biogeochem. Cy., 7, 927-957, 1993.

Milliman, J. D. and Droxler, A. W.: Neritic and pelagic carbonate sedimentation in the marine environment: ignorance is not bliss, Geol. Rundsch., 85, 496-504, 1996.

Mogollon, J. M., L'Heureux, I., Dale, A. W, and Regnier, P.: Methane gas-phase dynamics in marine sediments: A model study, Am. J. Sci., 309, 189-220, 2009.

Mollenhauer, G., Kienast, M., Lamy, F., Meggers, H., Schneider, R. R., Hayes, J. M., and Eglinton, T. I.: An evaluation of ${ }^{14} \mathrm{C}$ age relationships between co-occurring foraminifera, alkenones, and total organic carbon in continental margin sediments, Paleoceanography, 20, PA1016, doi:10.1029/2004PA001103, 2005.

Mollenhauer, G. and Eglinton, T. I.: Diagenetic and sedimentological controls on the composition of organic matter preserved in California Borderland Basin sediments, Limnol. Oceanogr., 52, 558-576, 2007.

Morse, J. W. and Mackenzie, F. T.: Geochemistry of sedimentary carbonates, Elsevier, Amsterdam, 1990.

Morse, J. W. and Mucci, A.: Composition of carbonate overgrowths produced on Iceland spar calcite crystals buried in Bahamian carbonate-rich sediments, Sediment. Geol., 40, 287-291, 1984.

Morse, J. W., Andersson, A. J., and Mackenzie, F. T.: Initial responses of carbonate-rich shelf sediments to rising atmospheric $p \mathrm{CO}_{2}$ and, Geochim. Cosmochim. Ac., 70, 5814-5830, 2006.

Morse, J. W. and Eldridge, P. M.: A non-steady state diagenetic model for changes in sediment biogeochemistry in response to seasonally hypoxic/anoxic conditions, Mar. Chem., 106, 239255, 2007,

Mucci, A., Sundby, B., Gehlen, M., Arakaki, T., Zhong, S., and Silverberg, N.: The fate of carbon in continental shelf sediments of 
eastern Canada: a case study, Deep Sea-Res. Pt. II, 47, 733-760, 2000.

Muller-Karger, F. E., Varela, R., Thunell, R., Luerssen, R., Hu, C., and Walsh, J. J.: The importance of continental margins in the global carbon cycle, Geophys. Res. Lett., 32, L01602, doi:10.1029/2004GL021346, 2005.

Munhoven, G.: Glacial-interglacial rain ratio changes: Implications for atmospheric $\mathrm{CO}_{2}$ and ocean-sediment interaction, Deep-Sea Res. Pt. II, 54, 722-746, 2007.

Orr, J. C., Fabry, V. J., Aumont, O., Bopp, L., Doney, S. C., Feely, R. A., Gnanadesikan, A., Gruber, N., Ishida, A., and Joos, F.: Anthropogenic ocean acidification over the twenty-first century and its impact on calcifying organisms, Nature, 437, 681-686, 2005.

Palastanga, V., Slomp, C. P., and Heinze, C.: Long-term controls on ocean phosphorus and oxygen in a global biogeochemical model, Global Biogeochem. Cy., 25, GB3024, DOI: 10.1029/2010GB003827, 2011.

Poulton, S. W. and Raiswell, R.: The low-temperature geochemical cycle of iron: From continental fluxes to marine sediment deposition, Am, J. Sci., 302, 774-805, 2002.

Rabouille, C., Gaillard, J. F., Relexans, J. C., Treguer, P., and Vincendeau, M. A.: Recycling of organic matter in Antarctic sediments: A transect through the polar front in the Southern Ocean (Indian sector), Limnol. Oceanogr., 43, 420-432, 1998.

Raiswell, R.: Towards a global highly reactive iron cycle, J. Geochem. Explor., 88, 436-439, 2006.

Regnier, P., Mouchet, A., Wollast, R., and Ronday, F.: A discussion of methods for estimating residual fluxes in strong tidal estuaries, Cont. Shelf Res., 18, 1543-1571, 1998.

Regnier, P., O'Kane, J. P., Steefel, C. I., and Vanderborght, J. P.: Modeling complex multi-component reactive-transport systems: towards a simulation environment based on the concept of a Knowledge Base, Appl. Math. Model., 26, 913-927, 2002.

Regnier, P., Dale, A. W., Arndt, S., LaRowe, D. E., Mogollón, J., and Van Cappellen, P.: Quantitative analysis of anaerobic oxidation of methane $(\mathrm{AOM})$ in marine sediments: A modeling perspective, Earth-Sci. Rev., 106, 105-130, 2011.

Reimers, C., Friedrichs, C., Bebout, B., Howd, P., Huettel, M., Jahnke, R., MacCready, P., Ruttenberg, K., Sanford, L., and Trowbridge, J.: Coastal Benthic Exchange Dynamics: Skidaway Institute of Oceanography Technical Report TR-04-01, p. 92, 2004.

Ridgwell, A.: Interpreting transient carbonate compensation depth changes by marine sediment core modeling, Paleoceanography, 22, PA4102, doi:10.1029/2006PA001372, 2007.

Ridgwell, A. and Hargreaves, J. C.: Regulation of atmospheric $\mathrm{CO}_{2}$ by deep-sea sediments in an Earth system model, Global Biogeochem. Cy., 21, GB2008, doi:10.1029/2006GB002764, 2007.

Rojas, N. and Silva, N.: Early diagenesis and vertical distribution of organic carbon and total nitrogen in recent sediments from southern Chilean fjords (Boca del Guafo to Pulluche Channel), Investigaciones marinas, 33, 183-194, 2005.

Rusch, A., Huettel, M., Wild, C., and Reimers, C. E.: Benthic oxygen consumption and organic matter turnover in organic-poor, permeable shelf sands, Aquat. Geochem., 12, 1-19, 2006.

Sarmiento, J. L. and Gruber, N.: Ocean biogeochemical dynamics, Cambridge University Press, 2006.
Schneider, R. R., Schulz, H. D., and Hensen, C.: Marine carbonates: their formation and destruction, in: Marine Geochemistry, edited by: Schulz, H. D. and Zabel, M., Springer, Berlin, 311337, 2006.

Shaffer, G., Malskær Olsen, S., and Pepke Pedersen, J. O.: Presentation, calibration and validation of the low-order, DCESS Earth System Model (Version 1), Geosci. Model Dev., 1, 17-51, doi:10.5194/gmd-1-17-2008, 2008.

Smith, W. H. F. and Sandwell, D. T.: Global sea floor topography from satellite altimetry and ship depth soundings, Science, 277, 1956-1962, 1997.

Soetaert, K., Herman, P. M. J., and Middelburg, J. J.: A model of early diagenetic processes from the shelf to abyssal depths, Geochim. Cosmochim. Ac., 60, 1019-1040, 1996.

Soetaert, K., Middelburg, J. J., Wijsman, J., Herman, P., and Heip, C.: Ocean Margin Early Diagenetic Processes and Models, Ocean Margin Systems, Springer-Verlag, Berlin, 157-177, 2002.

Spiteri C., Van Cappellen P., and Regnier P.: Surface complexation modeling of phosphate adsorption to iron(III)(hydr)oxides along $\mathrm{pH}$ and salinity gradients in estuaries and coastal aquifers, Geochim. Cosmochim. Ac., 72, 3431-3445, 2008.

Stockman, K. W., Ginsburg, R. N., and Shinn, E. A.: The production of lime mud by algae in South Florida, J. Sediment. Petrol. 37, 633-648, 1967.

Stumm, W. and Morgan, J. J.: Aquatic Chemistry: Chemical Equilibria and Rates in Natural Waters, 3rd Edn., John Wiley and Sons, Inc., New York, 1996

Suchet, A., Probst, J. L., and Ludwig, W.: Worldwide distribution of continental rock lithology: Implications for the atmospheric/soil $\mathrm{CO}_{2}$ uptake by continental weathering and alkalinity river transport to the oceans, Global Biogeochem. Cy., 17, 1038-1051, 2003.

Thomas, H., Schiettecatte, L.-S., Suykens, K., Koné, Y. J. M., Shadwick, E. H., Prowe, A. E. F., Bozec, Y., de Baar, H. J. W., and Borges, A. V.: Enhanced ocean carbon storage from anaerobic alkalinity generation in coastal sediments, Biogeosciences, 6, 267 274, doi:10.5194/bg-6-267-2009, 2009.

Thullner, M., van Cappellen, P., and Regnier, P.: Modeling the impact of microbial activity on redox dynamics in porous media, Geochim. Cosmochim. Ac., 69, 5005-5019, 2005,

Thullner, M., Dale, A. W., and Regnier, P.: Global-scale quantification of mineralization pathways in marine sediments: A reactiontransport modeling approach, Geochem. Geophys. Geosyst., 10, Q10012, doi:10.1029/2009GC002484, 2009.

Turner, R. E. and Rabalais, N. N.: Linking landscape and water quality in the Mississippi River Basin for 200 years, BioScience, 53, 563-572, 2003.

Walter, L. M. and Morse, J. W.: The dissolution kinetics of shallow marine carbonates in seawater: A laboratory study, Geochim. Cosmochim. Ac., 49, 1503-1513, 1985.

Wang, Y. and van Cappellen, P.: A multicomponent reactive transport model of early diagenesis: Application to redox cycling in coastal marine sediments, Geochim. Cosmochim. Ac., 60, 2993 3014, 1996.

Westrich, J. T. and Berner, R. A.: The role of sedimentary organic matter in bacterial sulfate reduction: The G model tested, Limnol, Oceanogr., 29, 236-249, 1984. 
Wollast, R.: The coastal organic carbon cycle: fluxes, sources and sinks in Ocean margin processes in global change, edited by: Mantoura, R. F. C., Martin, J. M., and Wollast, R., Wiley, Chichester NY, 365-381, 1991.
Wollast, R. and Mackenzie, F. T.: Global biogeochemical cycles and climate: NATO ASI series, Series C, Mathematical and physical sciences, 285, 453-473, 1989. 